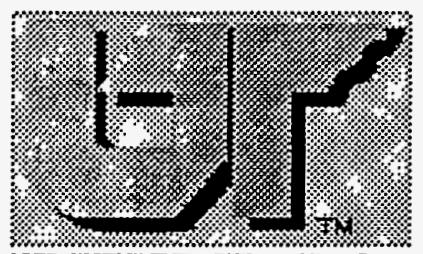

UNIVERSITY OF

TENNESSEE

\title{
Processing and Mechanical Behavior of Nicalon/SiC Composites with Sol-Gel Derived Oxide Interfacial Coatings
}

\author{
S. Shanmugham \\ P. K. Liaw
}

October 1996

Research sponsored by the U. S. Department of Energy, Office of Fossil Energy

Advanced Research and Technology Development Materials Program

Report prepared by

Department of Materials Science and Engineering

The University of Tennessee

434 Dougherty Engineering Bldg.

Knoxville, Tennessee 37996-2200

under

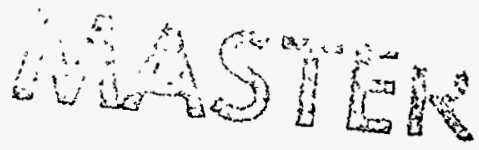

DOE/FE AA 1510100, Work Breakdown Structure Element

UT-1(B) under subcontract 11B-99732C-64

for

Oak Ridge National Laboratory

Oak Ridge, Tennessee 37831

Managed by

LOCKHEED MARTIN ENERGY RESEARCH CORP.

for the

U.S. DEPARTMENT OF ENERGY

32. 


\section{TABLE OF CONTENTS}

ABSTRACT

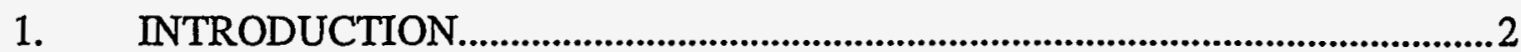

2. METHODOLOGY AND OXIDE INTERFACE CONCEPT...............................6

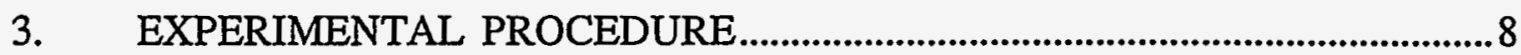

3.1. Mullite and Aluminosilicate Precursor Sols....................................................8

3.2. Aluminum Titanate Precursor Sol............................................................... 10

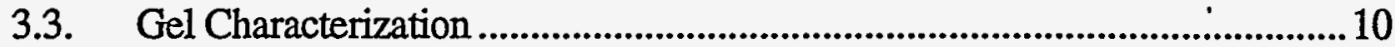

3.3.1. Differential Scanning Calorimetry..................................................... 10

3.3.2. High-Temperature X-ray Diffraction ..............................................10

3.4. Nicalon Cloth and Tow Studies....................................................................... 13

3.5. Composite Fabrication ...................................................................................13

3.6. Flexure Testing.......................................................................................14

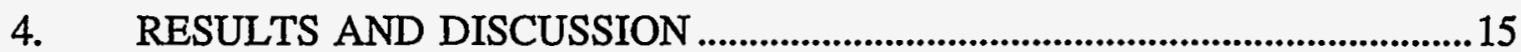

4.1. Gel Characterization ........................................................................................15

4.1.1. Differential Scanning Calorimetry...............................................15

4.1.2. High-Temperature X-ray Diffraction ............................................18

4.2. Nicalon Cloth and Tow Studies......................................................................18

4.3. Flexure Testing ………………………..............................................................24

4.4. Scanning Electron Microscopy .....................................................................22

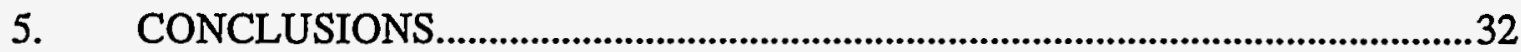

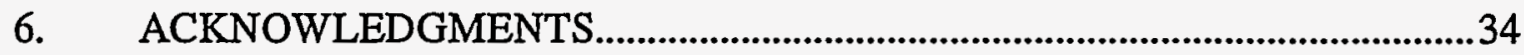

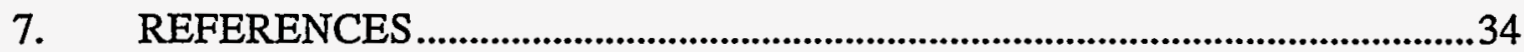




\section{DISCLAIMER}

Portions of this document may be illegible in electronic image products. Images are produced from the best available original document. 


\title{
Processing and Mechanical Behavior of Nicalon ${ }^{\circledR} / \mathrm{SiC}$ Composites with Sol- Gel Derived Oxide Interfacial Coatings
}

\author{
S. Shanmugham and P. K. Liaw
}

\begin{abstract}
Recent analytical and finite element modeling (FEM) studies have indicated that low modulus interface materials are desirable for obtaining Nicalon/SiC composites with good toughness. Two oxides, aluminum titanate and mullite, were chosen on this basis as interface materials. The oxide and carbon (C) coatings were deposited by a sol-gel and a chemical vapor deposition process, respectively. Nicalon/SiC composites with oxide/C and $\mathrm{C} / o x i d e / \mathrm{C}$ interfaces were fabricated and evaluated for flexure strength in the as-processed and oxidized conditions. Composites with $\mathrm{C} / o x i d e / \mathrm{C}$ interfaces retained considerable strength and damage-tolerant behavior even after $500 \mathrm{~h}$ oxidation at $1000^{\circ} \mathrm{C}$ in air. The $\mathrm{C} /$ oxide/ $\mathrm{C}$ interface shows promise as a viable oxidation-resistant interface alternative to $\mathrm{C}$ or $\mathrm{BN}$ interfaces.
\end{abstract}

Research sponsored by the U.S. Department of Energy, Fossil Energy Advanced Research and Technology Development Materials Program, DOE/FE AA 151010 0, Work Breakdown Structure Element UT-1(B)

- Ceramic Grade, Trade Mark of Nippon Carbon Company, Yokohama, Japan 


\section{INTRODUCTION}

During the last few decades there has been a strong interest in developing advanced ceramic materials for high-temperature structural applications in the aerospace, defense, and automotive industry $[1,2]$. Unfortunately, these materials lack significant stress-relieving mechanisms, and are inherently notch-sensitive and have low fracture toughness. To improve the strain and damage tolerance of ceramics, platelets, particles, whiskers, and continuous fibers have been introduced to create barriers to crack propagation [3-6]. The most dramatic improvement in toughness $\left(\mathrm{K}_{\mathrm{IC}}>20 \mathrm{MPa}-\mathrm{m}^{0.5}\right)$ has been obtained through reinforcement of continuous fibers in ceramic matrices $[5,6]$. The Nicalon/SiC composite is one such system [6]. Most of the nonoxide and oxide continuous fibers are compiled in Tables 1 and 2, respectively, along with their important thermal and mechanical properties [7-12]. However, carbon, silica, and other glass fibers are not included in this compilation. This is because there are many manufacturers for these fibers.

It is widely accepted that the interface between the fiber and the matrix plays a key role in determining the composite properties [13-16]. A strong interface promotes effective load transfer between the fiber and the matrix, however, it will not arrest an impinging matrix crack, and the composite will exhibit brittle failure [Fig. 1 (a)]. In contrast, a weak interface will allow matrix crack deflection and promote energy absorption through several mechanisms: debonding at the fiber-matrix interface, crack deflection, fiber bridging, fiber fracture, and fiber slip and pullout [Fig. 1(b)]. Delamination is sometimes observed and is also shown in Fig. 1(b).

Currently, Nicalon/SiC composites owe their damage tolerance at room temperature to $\mathrm{C}$ or BN interfaces between the fiber and the matrix $[13,16]$. However, $\mathrm{C}$ and $\mathrm{BN}$ interfaces are susceptible to oxidation at temperatures greater than $500^{\circ} \mathrm{C}$ and $900^{\circ} \mathrm{C}$, respectively [16]. Consequently, composites with these interfaces undergo degradation of mechanical properties, either strength or toughness or both, within $100 \mathrm{~h}$ at $1000^{\circ} \mathrm{C}$ [17-19]. To overcome this limitation, 


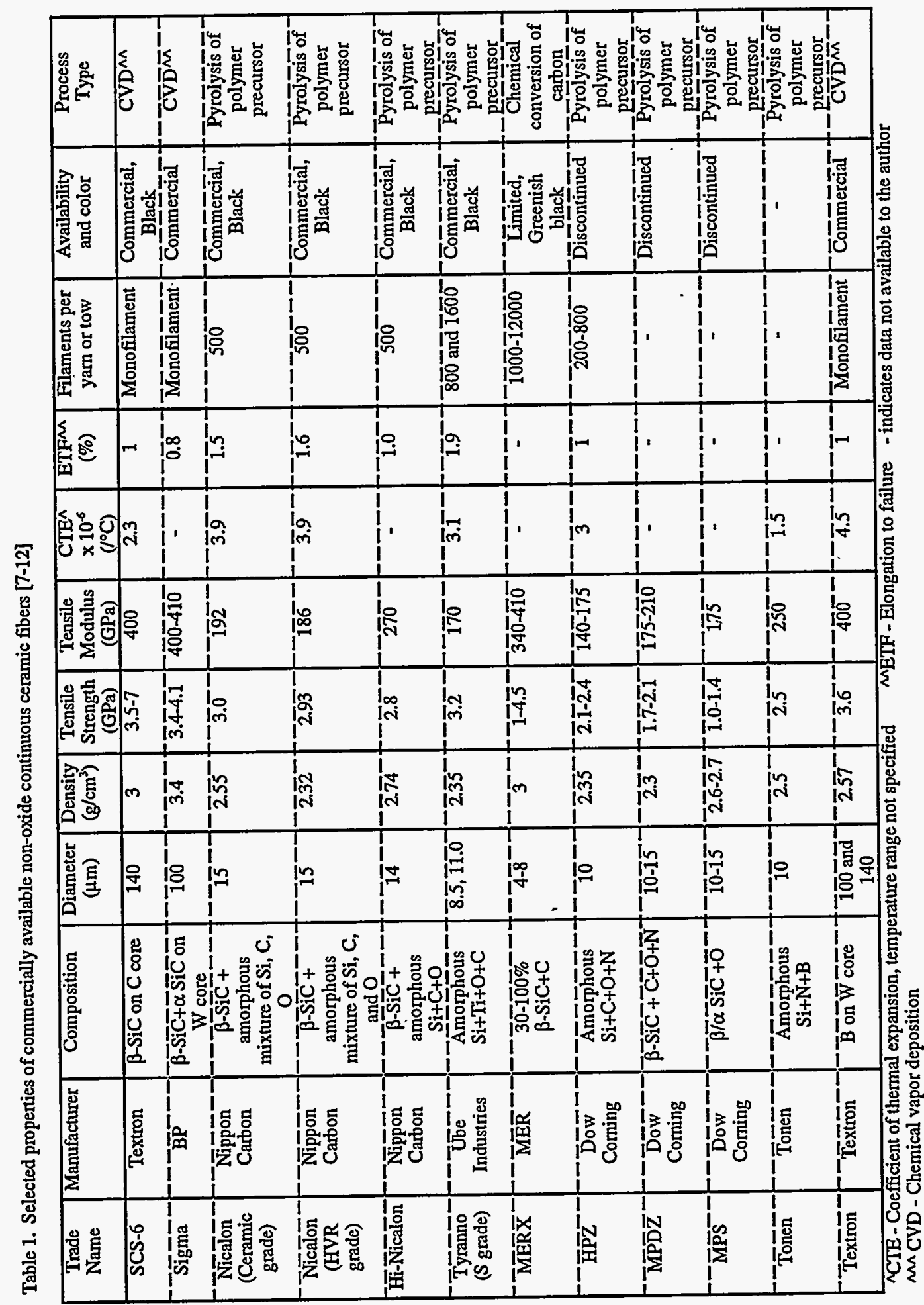


Table 2. Selected properties of commercially available oxide continuous ceramic fibers [7-12]

\begin{tabular}{|c|c|c|c|c|c|c|c|c|c|c|c|}
\hline $\begin{array}{l}\text { Trade } \\
\text { Name }\end{array}$ & Manufacturer & Composition & $\begin{array}{c}\text { Diameter } \\
(\mu \mathrm{m})\end{array}$ & $\begin{array}{l}\text { Density } \\
\left(\mathrm{g} / \mathrm{cm}^{3}\right)\end{array}$ & $\begin{array}{c}\text { Tensile } \\
\text { Strength } \\
\text { (GPa) }\end{array}$ & $\begin{array}{c}\text { Tensile } \\
\text { Modulus } \\
\text { (GPa) }\end{array}$ & $\begin{array}{l}\mathrm{CTE}^{\wedge} \\
\times 10^{-6} \\
\left(/^{\circ} \mathrm{C}\right)\end{array}$ & $\begin{array}{c}\text { ETF^A }^{\wedge} \\
(\%)\end{array}$ & $\begin{array}{c}\text { Filaments per } \\
\text { yam or tow }\end{array}$ & $\begin{array}{c}\text { Availability } \\
\text { and color }\end{array}$ & $\begin{array}{c}\text { Process } \\
\text { Type }\end{array}$ \\
\hline Saphikon & Saphikon & $\mathrm{Al}_{2} \mathrm{O}_{3}-100 \%$ & 125 & 3.97 & $2.1-3.4$ & $386-435$ & $7.9-8.8$ & $\begin{array}{l}11.5 \| \\
\text { to } c \\
\text { axis }\end{array}$ & Monofilament & $\begin{array}{l}\text { Commercial, } \\
\text { Translucent }\end{array}$ & Melt grown \\
\hline Fiber FP & $\bar{D} \bar{u} \bar{P} \bar{n} t$ & $\overline{\mathrm{Al}_{2}} \overline{\mathrm{O}_{3}}>\overline{99 \%}$ & $\overline{2} \overline{0}$ & 3.9 & $\overline{1} . \overline{4}$ & $3 \overline{80}$ & $6 . \overline{8}$ & -0.4 & 200 & $\begin{array}{l}\text { Discontinued, } \\
\text { White }\end{array}$ & șiurry-spun \\
\hline $\bar{A} \bar{l} \overline{m a x}$ & $\begin{array}{l}\text { Mitsui } \\
\text { Mining }\end{array}$ & $\overline{\mathrm{Al}}_{2} \overline{\mathrm{O}}_{3}>\overline{99 \%}$ & $\overline{15}$ & 3.6 & $\overline{1} . \overline{8}$ & $\overline{3} \overline{20}$ & & $\overline{0.5}$ & $\overline{1} \overline{00} \overline{0}$ & $\begin{array}{l}\text { Commercial, } \\
\text { White }\end{array}$ & Siurry-spun \\
\hline$\overline{\text { Nextel }} \overline{610}$ & $-\frac{3}{3}$ & $\begin{array}{l}\mathrm{Al}_{2} \mathrm{O}_{3}>99 \% \\
\mathrm{Fe}_{2} \mathrm{O}_{3}-0.4-0.7 \% \\
\mathrm{SiO}_{2}-0.2-0.3 \%\end{array}$ & $\overline{1} \overline{2}$ & $\overline{3} . \overline{8} \overline{8}$ & $\overline{1.9}$ & $3 \overline{73}$ & 7.9 & - & - & Commercial, & Sol-gè \\
\hline Safimax & $\overline{\mathbf{I}} \overline{\mathrm{I}}$ & $\begin{array}{c}\mathrm{Al}_{2} \mathrm{O}_{3}-95 \% \\
\mathrm{SiO}_{2}-5 \%\end{array}$ & 3 & $\overline{3.3}$ & $\overline{2}$ & 300 & $7-$ & - & Blanket & White- & \\
\hline Alltex & $\begin{array}{l}\text { Sumitomo } \\
\text { Chemical }\end{array}$ & $\begin{array}{l}-\mathrm{Al}_{2}=85 \% \\
\mathrm{SiO}_{2}-15 \%\end{array}$ & $\overline{10}, \overline{15}$ & 3.3 & $1 . \overline{8}$ & 210 & $\overline{8.8}$ & 0.8 & $\overline{500}$ and $\overline{1000}$ & $\begin{array}{l}\text { Commercial, } \\
\text { White }\end{array}$ & Sol-gel \\
\hline$\overline{\text { Nextel }} \overline{72} \overline{0}$ & $-\frac{1}{3}$ & $\begin{array}{l}\mathrm{Al}_{2} \mathrm{O}_{3}-85 \% \\
\mathrm{SiO}=15 \%\end{array}$ & $\overline{12}$ & 3.4 & $\overline{2} . \overline{1}$ & $260^{-}$ & 6.0 & - & $=$ & Commercial, & Sol-gè \\
\hline$\overline{\text { Nextel }} \overline{550} \overline{0}$ & $\overline{3} \bar{M}$ & $\begin{array}{l}\mathrm{Al}_{2} \mathrm{O}_{3}-73 \% \\
\mathrm{SiO}_{2}-27 \%\end{array}$ & $\overline{1} \overline{2}$ & $\overline{3} . \overline{0} \overline{3}$ & $2 . \overline{0}$ & $\overline{193}$ & $5 . \overline{3}$ & $=$ & $=$ & Commercial, & Söl-gel- \\
\hline $\bar{N} \overline{e x t e l} \overline{440} \overline{0}$ & $\overline{3} \bar{M}$ & $\begin{array}{l}-\mathrm{Al}_{2}-73 \% \\
\mathrm{SiO}_{2}-28 \% \\
\mathrm{~B}_{2} \mathrm{O}_{3}-2 \%\end{array}$ & $\overline{10}-\overline{12}$ & $\overline{3} . \overline{0} \overline{5}$ & $\overline{2} . \overline{0}$ & $\overline{190}$ & $5 . \overline{3}$ & - & - & $\begin{array}{c}\text { Commercial, } \\
\text { Pink }\end{array}$ & Sol-gel \\
\hline$\overline{\text { Nextel }} \overline{3} \overline{1} \overline{2}$ & $\overline{3} \bar{M}$ & $\begin{array}{l}\mathrm{Al}_{2} \mathrm{O}_{3}-64 \% \\
\mathrm{SiO}_{2}-24 \% \\
\mathrm{~B}_{2} \mathrm{O}_{3}-14 \%\end{array}$ & $\overline{10}-\overline{1} \overline{2}$ & 2.7 & $\overline{1.7}$ & 150 & $\overline{3}$ & - & - & $\begin{array}{c}\text { Commercial, } \\
\text { White }\end{array}$ & Sol-gei \\
\hline$\overline{\mathrm{P}} \overline{\mathrm{R}} \overline{\mathrm{D}}-\overline{1} \overline{\mathrm{C}} \overline{\mathrm{C}}$ & $\overline{\mathrm{D}} \overline{\mathrm{Pon}} \overline{\mathrm{P}}$ & $\begin{array}{l}\mathrm{Al}_{2} \mathrm{O}_{3}-80 \% \\
\mathrm{ZrO}_{2}-20 \%\end{array}$ & $\overline{2} \overline{0}$ & 4.2 & $2.0 \overline{7}$ & $\overline{3} 80^{-}$ & $\overline{9}$ & $0 . \overline{6}$ & $=$ & $\begin{array}{l}\text { Discontinued, } \\
\text { White }\end{array}$ & Slurry-spun \\
\hline $\begin{array}{l}\text { Nexte- } \\
\text { Z-11 }\end{array}$ & $\overline{3} \bar{M}$ & $\begin{array}{l}-\mathrm{ZrO}_{2}-68 \% \\
\mathrm{SiO}_{2}-32 \%\end{array}$ & $\overline{1} \overline{4}$ & 3.7 & $\overline{1.3}$ & 76 & - & - & & & Sol-gel \\
\hline
\end{tabular}

${ }^{\wedge} \mathrm{CTE}$ - Coefficient of thermal expansion, temperature range not specified

METF - Elongation to failure - indicates data not available to the author 


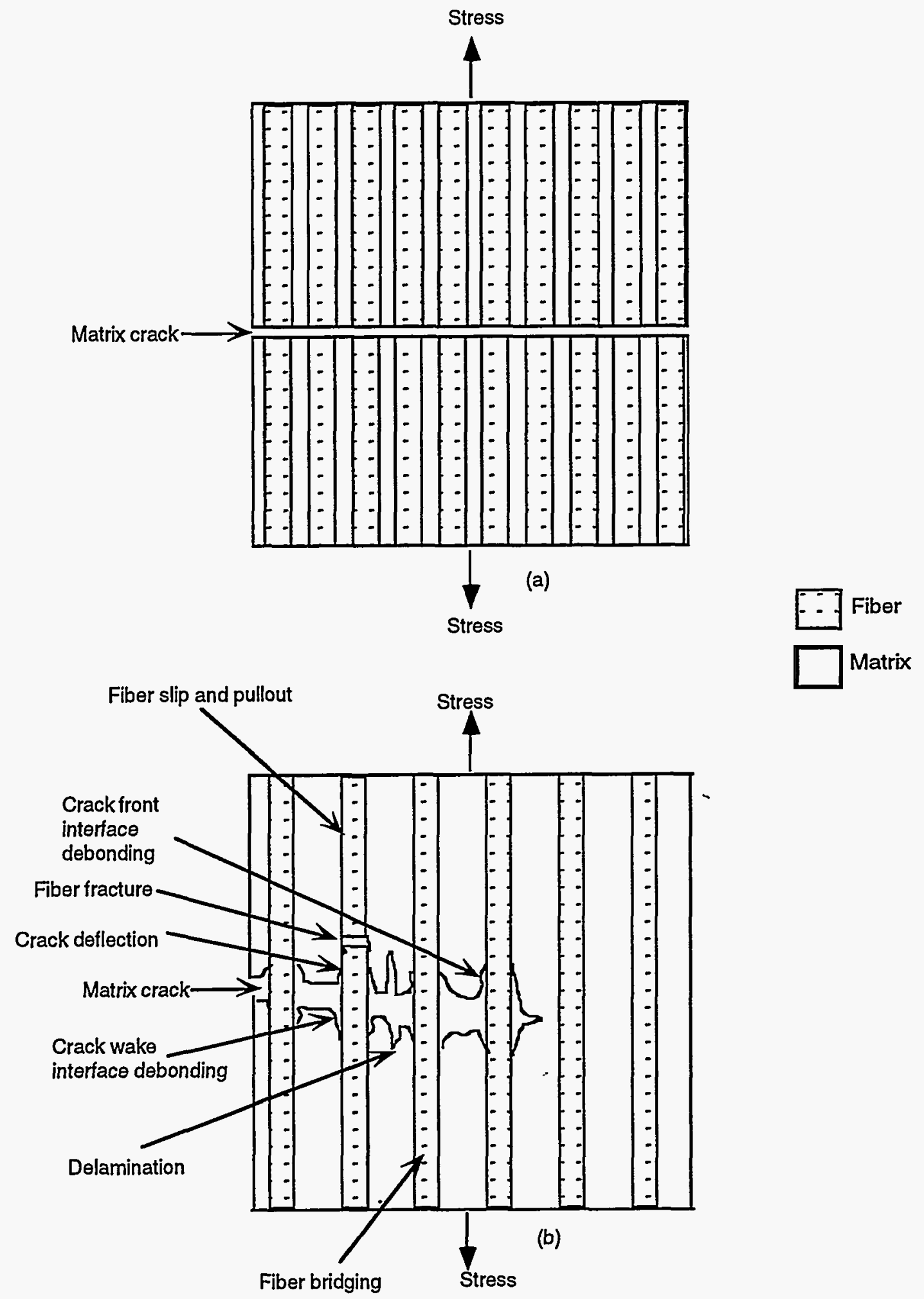

Fig. 1 Effect of interface bond on the failure of a ceramic matrix composite (a) strong interface (b) weak interface 
several interface materials, such as silicon, boron, molybdenum, boron-doped C, alumina, zirconia, and titania, have been investigated for attaining high-strength and high-toughness composites at elevated temperatures [15, 20-22]. However, there has been limited success.

Generally, metal oxides are inherently stable in air and possess thermal expansion coefficients relatively close to those of Nicalon and SiC. Hsueh et al. [23] indicated that a lowmodulus interfacial coating would be effective in reducing the radial stresses that result upon cooling from processing to room temperature in composites, where the fiber has a lower thermal expansion coefficient than the matrix, and enhance fiber pullout. The FEM results of Shanmugham et al. [15] were similar to the analytical modeling predictions of Hsueh et al. [23]. Accordingly, the objective of the present study is to investigate the above hypothesis, with aluminum titanate $(\mathrm{E}=20 \mathrm{GPa}$, a low modulus material $)$ and mullite $(\mathrm{E}=140 \mathrm{GPa}$, a moderate modulus material) as interface materials.

\section{METHODOLOGY AND OXIDE INTERFACE CONCEPT}

A Nicalon/SiC composite with a sol-gel derived mullite interface (50 nm thick) has been previously described (Fig. 2) [24]. However, this composite exhibited brittle fracture and could be attributed to the degradation of the Nicalon fibers during the sol-gel processing of the oxide. Hence, there is a need to apply an inert material between the fiber and oxide during the oxide deposition. For this purpose, a thin inner $C$ coating ( $<50 \mathrm{~nm}$ thick) was chosen. Thermodynamic modeling studies performed by Walukas [22] indicated that oxide coatings of alumina, titania, and zirconia would be attacked by $\mathrm{HCl}$, a by-product of the $\mathrm{SiC}$ matrix formation reaction. To prevent the $\mathrm{HCl}$ attack on the oxide coating, an inert material between the oxide and $\mathrm{SiC}$ is desirable. Hence, a thin outer $\mathrm{C}$ coating ( $<50 \mathrm{~nm}$ thick) was deposited. Earlier, Lowden [19] noted that such thickness of the $\mathrm{C}$ layer in a Nicalon/SiC composite would not produce good mechanical properties. 


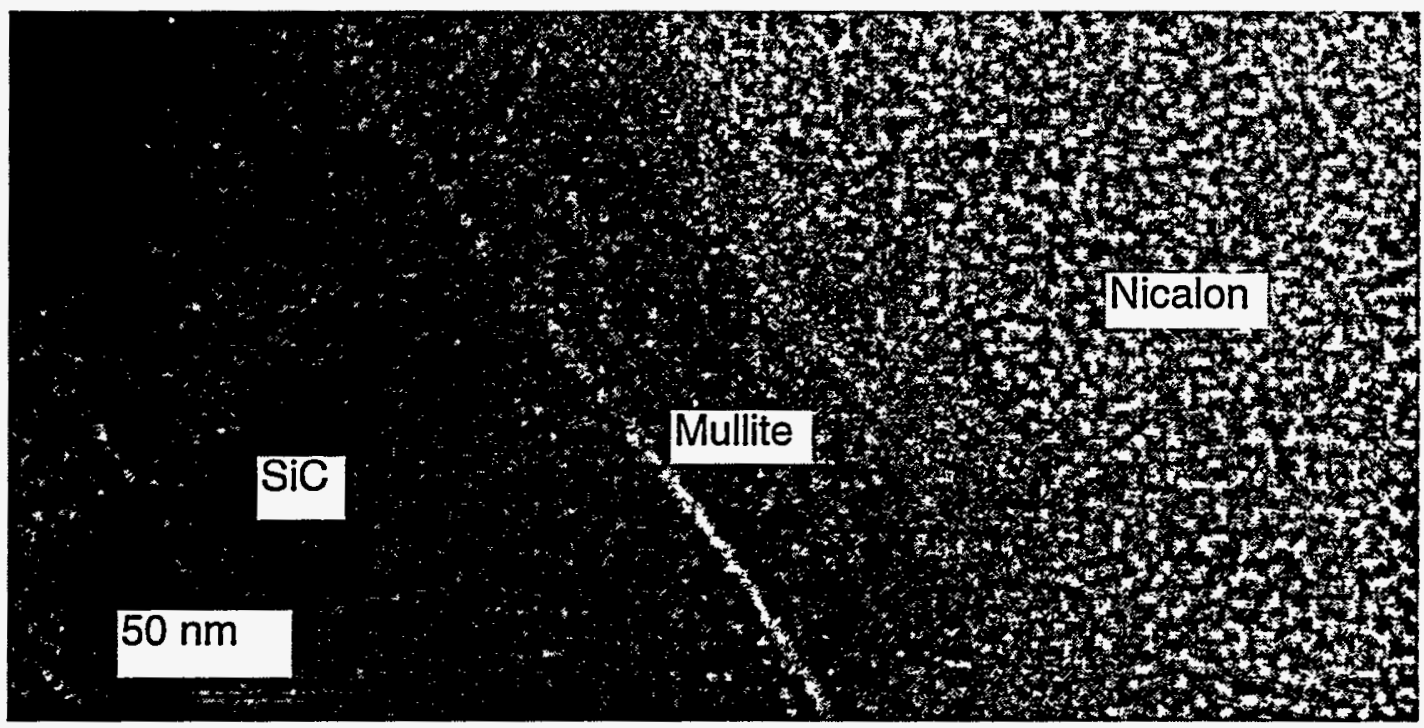

Fig. 2 TEM image of a Nicalon/SiC composite with a mullite interface. 
Two different interfaces were considered for Nicalon/SiC composites: oxide/C and C/oxide/C. A composite with a Cloxide/C interface is termed as a composite with an oxide interface concept as shown in Fig. 3. For the oxide/C interface, the oxide is adjacent to the fiber and the $\mathrm{C}$ is between the oxide and the matrix. While in the $\mathrm{C} /$ oxide/ $\mathrm{C}$ interface, the $\mathrm{C}$ on the extreme left is adjacent to the fiber, and the $\mathrm{C}$ on the extreme right is before the matrix. The oxide/C interface would be able to identify the degradation of the fiber, if any, during the sol-gel processing of the oxide. While in the C/oxide/C interface, the fiber is protected during the oxide deposition by the sol-gel method. To investigate the effect of modulus and the significance of the protection of the fiber during the sol-gel processing of the oxide on the composite properties, Nicalon/SiC composites with the following interfaces were fabricated: (1) mullite/C, (2) aluminatitania/C, (3) C/mullite/C, and (4) C/alumina-titania/C.

\section{EXPERIMENTAL PROCEDURE}

\subsection{Mullite and Aluminosilicate Precursor Sols}

The procedure used for the preparation of the mullite precursor sol has been slightly modified from that of Yoldas [25]: The mullite sol has a lower molar concentration; the amount of water added for hydrolysis during the stages of sol formation and gelation is different; and no acid catalyst is employed during the formation of the mullite precursor sol. $105 \mathrm{~g}$ ethanol was added to $1.5 \mathrm{~g}$ water in a flask. To this mixture, $30.8 \mathrm{~g}$ aluminum sec-butoxide (ASB) was added, and the solution was shaken to form a white slurry. This white slurry converted to a clear, waterlike liquid within $12 \mathrm{~h}$ when kept at $55^{\circ} \mathrm{C}$, and is termed as the alumina precursor sol.

Two different mullite sols were obtained: To about $60 \mathrm{cc}$ alumina precursor sol, either 2.23 cc tetramethoxysilane (TMOS) or $3.35 \mathrm{cc}$ tetraethoxysilane (TEOS) was added. Then, $0.27 \mathrm{cc}$ water mixed with $50 \mathrm{cc}$ ethanol was added to produce a clear, water-like liquid and is referred to as the mullite precursor sol. The mullite precursor sol obtained from the ASB/TMOS formulation 


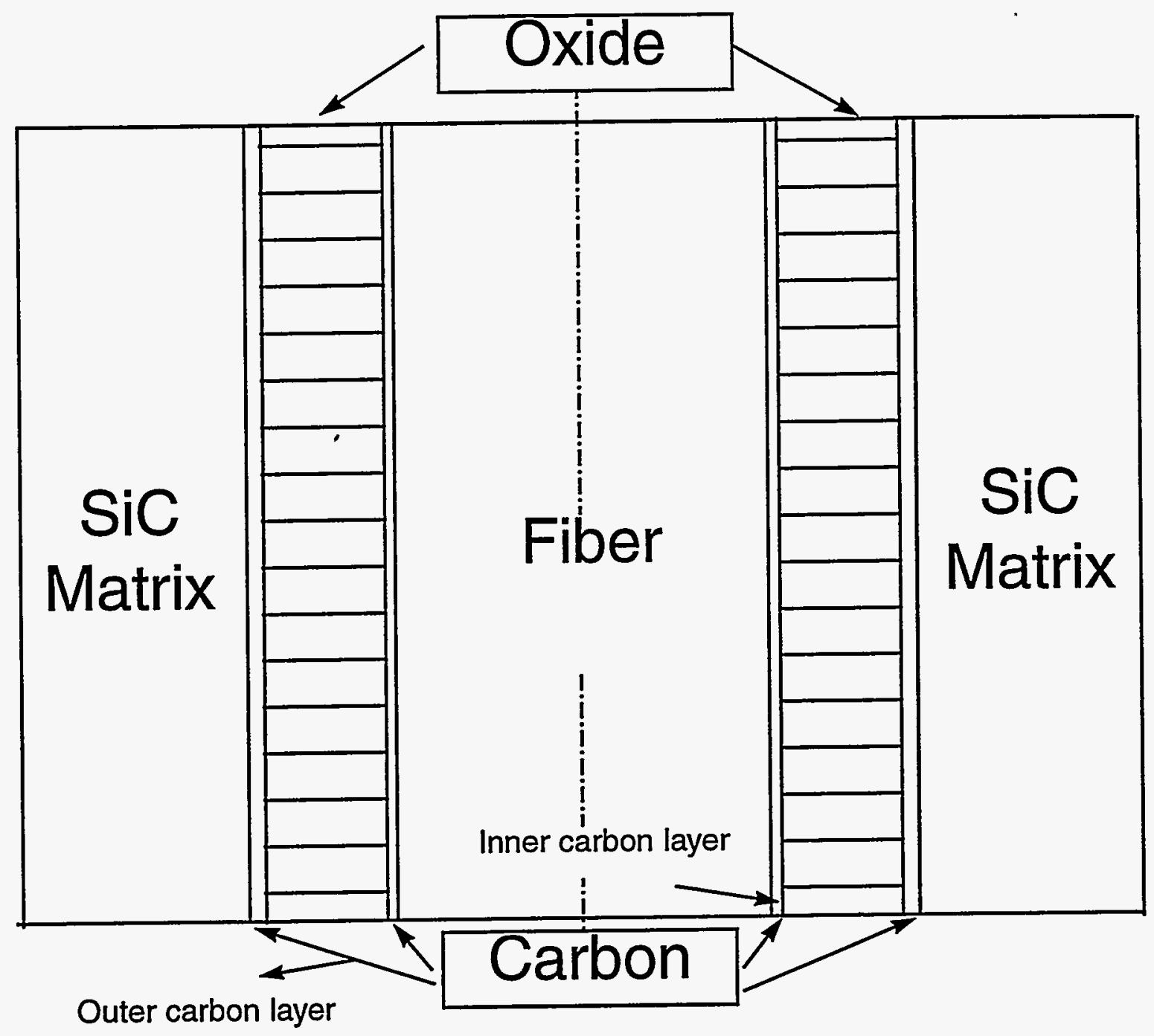

Inner Carbon Layer - Protects the fiber during the sol-gel processing of the oxide

Outer Carbon Layer - Protects the oxide coating from $\mathrm{HCl}$ attack during the chemical vapor infiltration processing of the $\mathrm{SiC}$ Matrix

Fig. 3. Oxide interface concept for a fiber-reinforced ceramic matrix composite. 
and the ASB/TEOS combination are termed as MI and MII, respectively. For gelation studies, $2.71 \mathrm{cc}$ water in $25 \mathrm{cc}$ ethanol was then poured into each of the mullite sols (MI and MII) and gelled at $60^{\circ} \mathrm{C}$. This gel was dried at $60^{\circ} \mathrm{C}$ for $168 \mathrm{~h}$. The process procedure is summarized in Fig. 4. Additionally, aluminosilicate precursor sols with final alumina/silica ratios of 0.75 and 3 were synthesized using the ASB/TEOS combination. The following recipe was used for preparing the mullite precursor sol for coating virgin or C-coated Nicalon preforms: alumina sol$60 \mathrm{cc}$, TEOS-3.35 cc, distilled water- $0.4 \mathrm{cc}$, and ethanol-50 cc.

\subsection{Aluminum Titanate Precursor Sol}

For synthesizing the aluminum titanate precursor sol, $10 \mathrm{cc}$ titanium ethoxide (TEOD) was first dissolved in $40 \mathrm{cc}$ 2-methoxyethanol. $23.62 \mathrm{cc}$ of the above mixture was then poured into 60 $\mathrm{cc}$ of the alumina precursor sol. Next, $0.27 \mathrm{cc}$ water in $50 \mathrm{cc}$ ethanol was added to produce a aluminum titanate precursor sol. For gelation studies, $3.25 \mathrm{cc}$ water in $25 \mathrm{cc}$ ethanol was poured into the aluminum titanate sol and gelled and dried at $60^{\circ} \mathrm{C}$ for $168 \mathrm{~h}$. The process flowchart is summarized in Fig. 5. The following recipe was used for preparing the aluminum titanate precursor sol for coating virgin or C-coated Nicalon preforms: alumina sol-80 cc, TEOD in 2methoxyethanol-25.76 cc, distilled water-1 cc, and ethanol-100 cc.

\subsection{Gel Characterization}

\subsubsection{Differential Scanning Calorimetry}

Differential scanning calorimetry (DSC) runs were conducted in a Pt crucible with sapphire (45 mg) as the reference material and about $40-50 \mathrm{mg}$ of the precursor powder obtained from the gel as the test sample. The DSC furnace was ramped at $20^{\circ} \mathrm{C} / \mathrm{min}$ between $20^{\circ} \mathrm{C}$ and $1450^{\circ} \mathrm{C}$, and the measurements were conducted in air.

\subsubsection{High-Temperature X-ray Diffraction}

High-temperature $X$-ray diffraction $(\mathrm{XRD})$ patterns were obtained using a Scintag PAD X $\theta / \theta$ diffractometer equipped with a $\mathrm{Cu} \mathrm{X}$-ray tube, a Buehler high-temperature furnace and an 


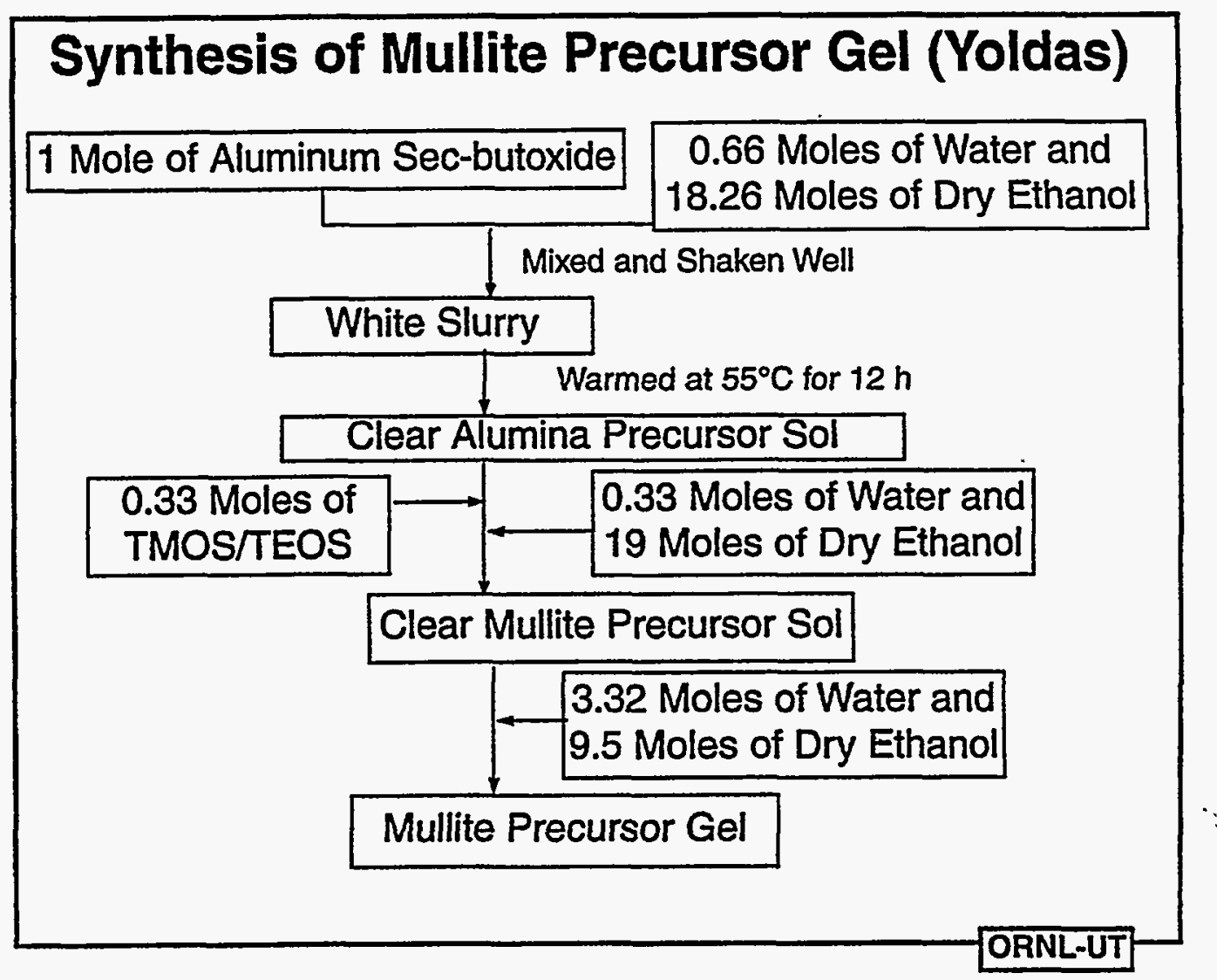

Fig. 4 Flow diagram of the synthesis of mullite precursor gel using Yoldas' method. 


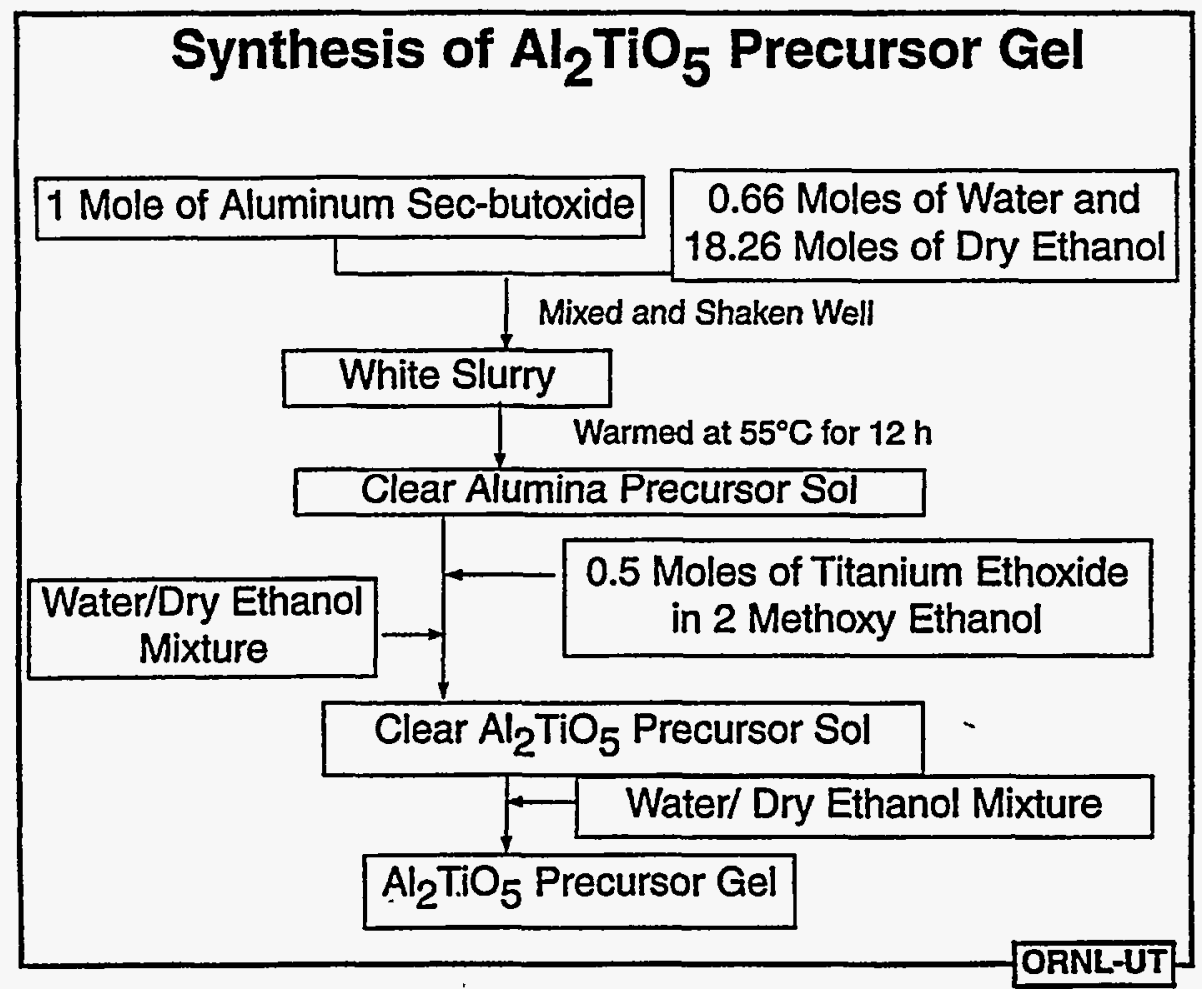

Fig. 5 Flow diagram of the synthesis of aluminum titanate precursor gel. 
mBraum position-sensitive detector. The XRD patterns were collected in a dynamic air atmosphere $\left(100 \mathrm{~cm}^{3} / \mathrm{min}\right)$ over the scan range of $20^{\circ}$ to $70^{\circ} 2 \theta$ at $5 \% \mathrm{~min}$ and at several temperatures up to $1350^{\circ} \mathrm{C}$ for the mullite precursor gel and $1450^{\circ} \mathrm{C}$ for the aluminum titanate precursor gel. For the MI and MII mullite precursor powders, the XRD patterns were obtained at $27^{\circ} \mathrm{C}, 700^{\circ} \mathrm{C}, 750^{\circ} \mathrm{C}, 800^{\circ} \mathrm{C}, 900^{\circ} \mathrm{C}, 950^{\circ} \mathrm{C}, 1000^{\circ} \mathrm{C}, 1050^{\circ} \mathrm{C}, 1100^{\circ} \mathrm{C}, 1200^{\circ} \mathrm{C}$, and $1350^{\circ} \mathrm{C}$ during heating, and at $50^{\circ} \mathrm{C}$ after cooling. Heating rates were $50^{\circ} \mathrm{C} / \mathrm{min}$ up to $1100^{\circ} \mathrm{C}$, and $20^{\circ} \mathrm{C} / \mathrm{min}$ above $1100^{\circ} \mathrm{C}$. The cooling rate was $100^{\circ} \mathrm{C} / \mathrm{min}$.

For the aluminum titanate precursor powder, the XRD patterns were obtained at $27^{\circ} \mathrm{C}$, $500^{\circ} \mathrm{C}, 600^{\circ} \mathrm{C}, 700^{\circ} \mathrm{C}, 800^{\circ} \mathrm{C}, 900^{\circ} \mathrm{C}, 950^{\circ} \mathrm{C}, 1000^{\circ} \mathrm{C}, 1050^{\circ} \mathrm{C}, 1100^{\circ} \mathrm{C}, 1200^{\circ} \mathrm{C}, 1300^{\circ} \mathrm{C}$, $1350^{\circ} \mathrm{C}, 1400^{\circ} \mathrm{C}$, and $1450^{\circ} \mathrm{C}$, during heating, and at $50^{\circ} \mathrm{C}$ during cooling. Heating rates were $50^{\circ} \mathrm{C} / \mathrm{min}$ up to $1000^{\circ} \mathrm{C}$, and $20^{\circ} \mathrm{C} / \mathrm{min}$ above $1100^{\circ} \mathrm{C}$. The cooling rate was $100^{\circ} \mathrm{C} / \mathrm{min}$. The obtained XRD patterns were identified by comparing with the International Centre for Diffraction Data (ICDD) patterns of mullite, $\alpha$-alumina, titania, and aluminum titanate.

\subsection{Nicalon Cloth and Tow Studies}

Nicalon cloth $(6.35 \mathrm{~mm}$ in diameter) was dipped in the mullite (MII) sol with concentrations ranging from 1 to $4.87 \mathrm{wt} \%$, and heat treated at $1000^{\circ} \mathrm{C}$ for $1 \mathrm{~h}$ in air. Following this, the samples were examined in a scanning electron microscope to determine the coating characteristics. Nicalon tows $15 \mathrm{~cm}$ long were withdrawn from the 3 wt\% mullite (both MI and MII) precursor sols, and aluminum titanate precursor sols at the rate of $3.7 \mathrm{~cm} / \mathrm{min}$. The coated tows were then heated in air at $1000^{\circ} \mathrm{C}$ for $1 \mathrm{~h}$ or $10 \mathrm{~h}$. Additionally, Nicalon tows were dip-coated in aluminosilicate sols with different alumina/silica ratios, and heat treated at $1000^{\circ} \mathrm{C}$ for $1 \mathrm{~h}$.

\subsection{Composite Fabrication}

The Nicalon preform (50 layers) was prepared by stacking multiple layers of the corresponding cloth (45 mm dia) in a $0^{\circ} / 30^{\circ} / 60^{\circ}$ sequence within the cavity of a graphite holder (12.5 mm thick). The preform was hand-compressed and held within the holder by a graphite lid. 
Thin inner $\mathrm{C}$ coatings were deposited in some cases on the fibrous preform (prior to the oxide deposition by the sol-gel route). Thin outer $\mathrm{C}$ coatings were deposited on the sol-gel oxide in all cases prior to the $\mathrm{SiC}$ matrix infiltration. The $\mathrm{C}$ coating was deposited by a chemical vapor deposition process under isothermal and reduced pressure conditions. This process was conducted under the following conditions within the furnace used for chemical vapor infiltration (CV): $1100^{\circ} \mathrm{C}, 1-2 \mathrm{kPa}$, gas flows of $25 \mathrm{~cm}^{3} / \mathrm{min}$ propylene, and $500 \mathrm{~cm}^{3} / \mathrm{min}$ argon for $15 \mathrm{~min}$.

The mullite precursor coatings were applied either on a virgin or C-coated Nicalon preform by vacuum infiltration of the mullite precursor sol (MII) followed by drying at $110^{\circ} \mathrm{C}$. This step was repeated 3-4 times till a final coating thickness of 150-300 nm was obtained (based on weight gain). Then the corresponding mullite and alumina-titania precursor-coated preforms were heat treated in argon at $1050^{\circ} \mathrm{C}$ for $1 \mathrm{~h}$ to obtain mullite and alumina-titania coatings, respectively.

The SiC matrix was infiltrated using a forced-flow CVI process developed at the Oak Ridge National Laboratory and is described elsewhere [26]. The process parameters used for the $\mathrm{SiC}$ infiltration are as follows: top surface temperature of $1200^{\circ} \mathrm{C}$; methyltrichlorosilane flow of $0.3 \mathrm{~g} / \mathrm{min}$ and hydrogen flow of $500 \mathrm{~cm}^{3} / \mathrm{min}$; and the exhaust pressure of $101 \mathrm{kPa}$. Typically, the $\mathrm{SiC}$ matrix infiltration was completed within 20 hours. Nicalon/SiC composites with the following interfaces were fabricated: (1) mullite/C interface, (2) alumina-titania/C interface, (3) $\mathrm{C} /$ mullite/C interface, and (4) C/alumina-titania/C interface. The basis for depositing an aluminatitania interface instead of an aluminum titanate interface would be explained in the results and discussion section.

\subsection{Flexure Testing}

Twenty four flexure bars of dimensions, $\sim 2.5 \times 3.0 \times>33 \mathrm{~mm}$, were obtained from each composite disk. The geometrical density of each of the flexure bars was determined from the weight and dimension measurements of the bar. 
The flexure strengths of the composites were determined at room temperature in both asprocessed and after oxidation at $1000^{\circ} \mathrm{C}$ in air. Twelve flexure bars of each of the fabricated composites were tested in the as-processed condition. For Nicalon/SiC composites with low strength $(<150 \mathrm{MPa}$ ) in the as-processed condition, the remaining 12 bars were oxidized at $1000^{\circ} \mathrm{C}$ for $24 \mathrm{~h}$ in air, and subsequently tested at room temperature. In the case of composites with moderate strength ( $>225 \mathrm{MPa}$ ) in the as-processed condition, the remaining 12 bars were oxidized at $1000^{\circ} \mathrm{C}$ in air as follows: 6 bars for $24 \mathrm{~h}, 3$ bars for $200 \mathrm{~h}$, and 3 bars for $500 \mathrm{~h}$. The fracture surfaces of the as-processed and oxidized samples were examined using a scanning electron microscope.

\section{RESULTS AND DISCUSSION}

\subsection{Gel Characterization}

\subsubsection{Differential Scanning Calorimetry}

The DSC curve obtained from the powder derived from the mullite precursor gel, MI, is shown in Fig. 6. The DSC curves of MI and MII gel show an initial endothermic peak around $150^{\circ} \mathrm{C}$ corresponding to a water loss followed by two broad exothermic peaks above $220^{\circ} \mathrm{C}$ and below $650^{\circ} \mathrm{C}$. These exothermic peaks are associated with organics being burnt out. This is followed by a sharp exothermic peak around $990^{\circ} \mathrm{C}$ corresponding to mullite crystallization. Further, the mullite crystallization temperature is the same for both TMOS-ASB (MI) and TEOSASB (MII) combinations and is similar to Yoldas' result [25]. The DSC curve obtained from an aluminum titanate precursor gel is shown in Fig. 7. An endothermic peak is observed around $150^{\circ} \mathrm{C}$ and corresponds to a water loss. This is followed by three exothermic peaks above $220^{\circ} \mathrm{C}$ and below $600^{\circ} \mathrm{C}$, which correspond to the organics being burnt off. Subsequently, titania crystallizes between 700 and $900^{\circ} \mathrm{C}$, and $\alpha$-alumina crystallizes around $1000^{\circ} \mathrm{C}$, respectively. Then alumina and titania react to form aluminum titanate between $1340^{\circ} \mathrm{C}$ and $1400^{\circ} \mathrm{C}$ (Fig. 7). 


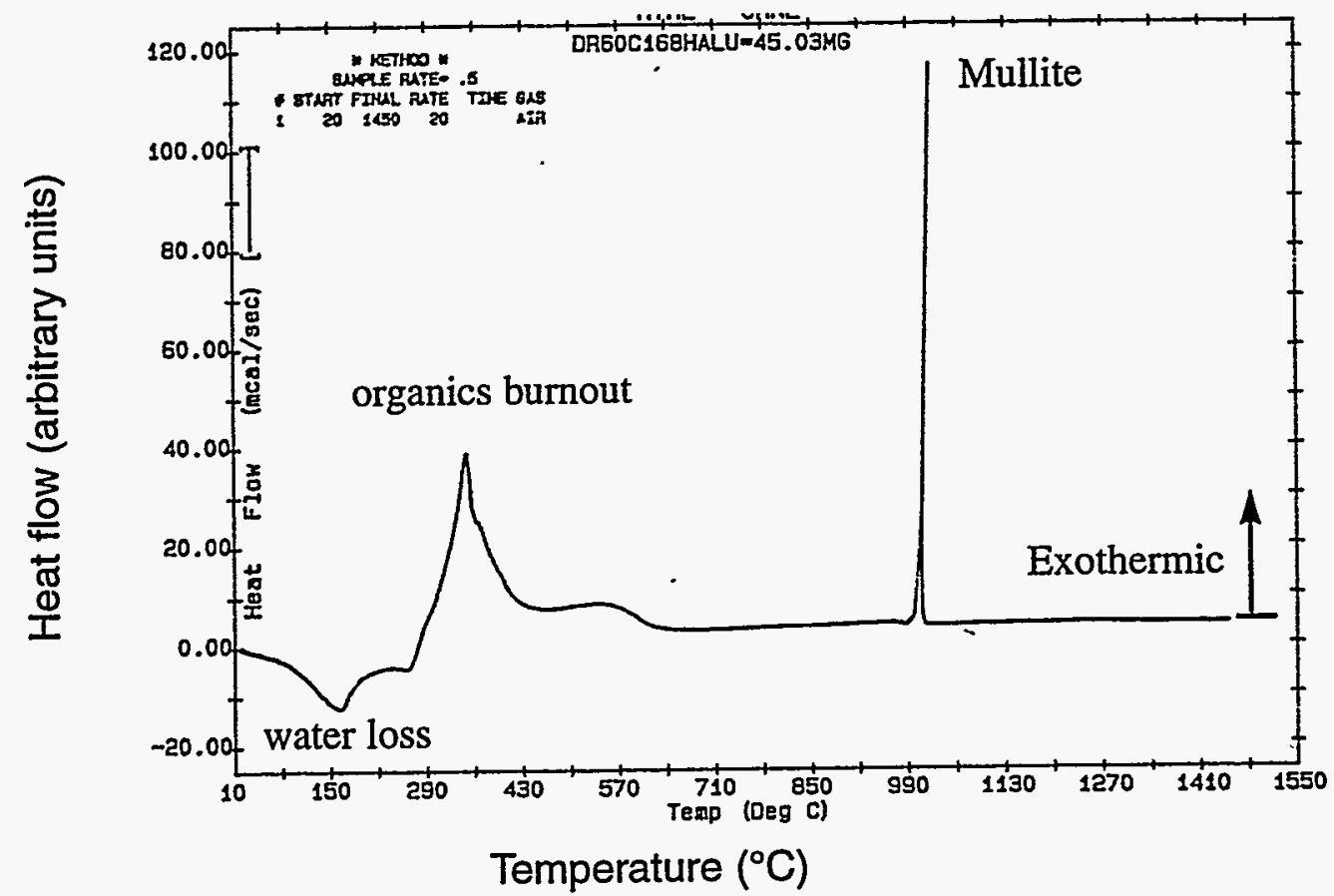

Fig. 6 DSC curve of the powder obtained from the mullite precursor gel (MI) using the ASB-TMOS combination. 


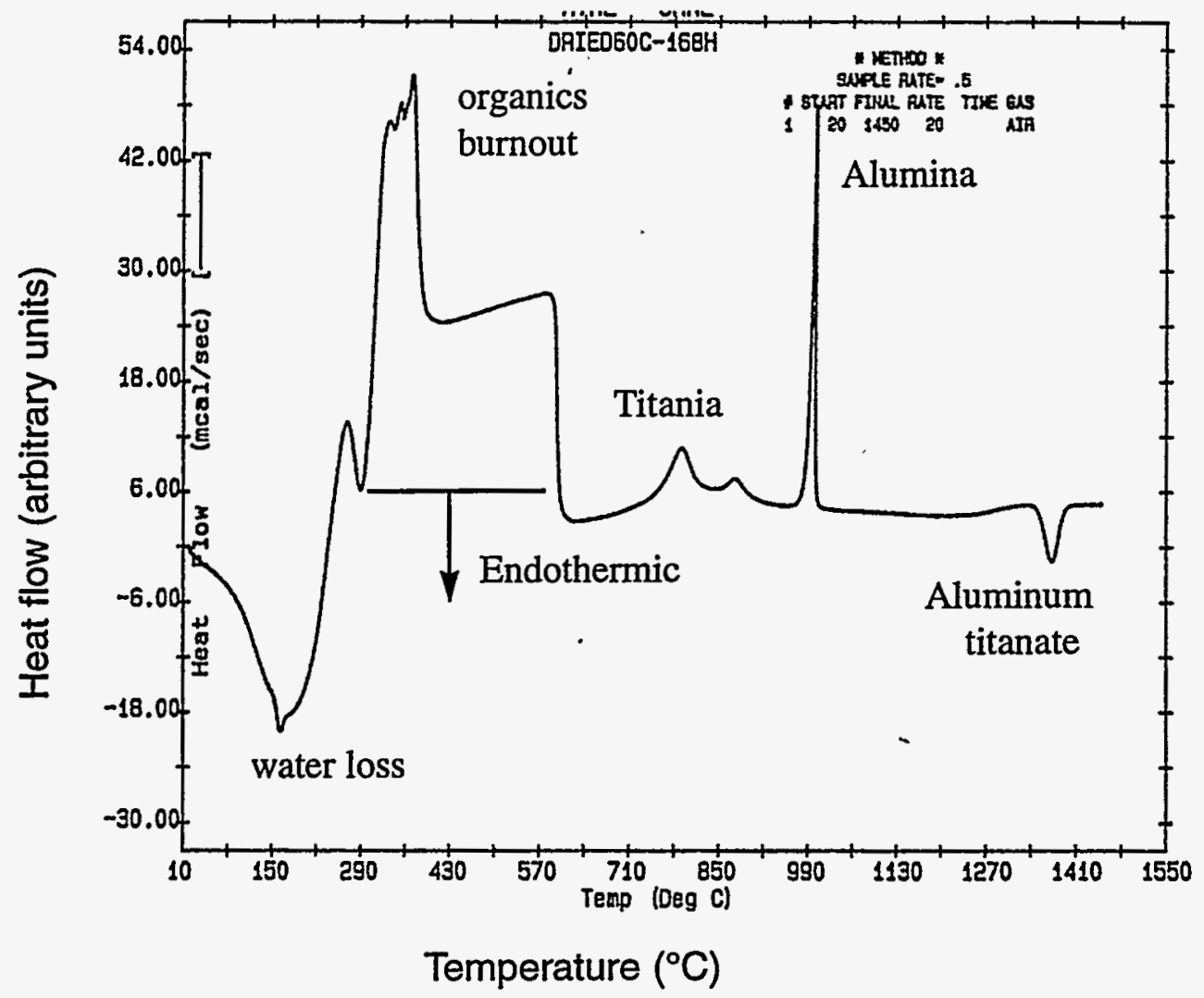

Fig. 7 DSC curve of the powder obtained from the aluminum titanate precursor gel. 


\subsubsection{High-Temperature $X$-ray Diffraction}

High-temperature XRD patterns obtained from the MII gel derived powder is shown in Fig. 8. It is evident from Fig. 8 that at room temperature there are three peaks corresponding to the substrate $\mathrm{Pt}-\mathrm{Rh}$, and these peaks are present in the XRD patterns at all temperatures. From room temperature to $1000^{\circ} \mathrm{C}$, only the substrate peaks are present. At $1050^{\circ} \mathrm{C}$, mullite peaks are present in addition to the substrate peaks, and match well with the ICDD pattern for mullite. These mullite peaks continue to be present till $1350^{\circ} \mathrm{C}$ (\# 11 in Fig. 8) and can be quenched to $50^{\circ} \mathrm{C}$ (\# 12 in Fig. 8). Similar evolution of the mullite peaks (at $1050^{\circ} \mathrm{C}$ ) is observed from the powder derived from the MI gel, and earlier, Yoldas' [25] made similar observation. Hence, if a Nicalon cloth is dipcoated at room temperature, dried, and heat treated at $1050^{\circ} \mathrm{C}$ in air, a mullite coating can be obtained. The mullite crystallization temperature is not high enough to cause degradation of Nicalon fibers.

The high-temperature XRD results are consistent with the DSC results (Fig. 7) for aluminum titanate. The high-temperature XRD patterns also show that titania cystallization occurs at $900^{\circ} \mathrm{C}$ followed by alumina crystallization at $1000^{\circ} \mathrm{C}$ (Fig. 9). Alumina and titania then react to form aluminum titanate around $1400^{\circ} \mathrm{C}$. This formation temperature is very high and would degrade Nicalon fibers. Additionally, residual amounts of alumina and titania remain at $1400^{\circ} \mathrm{C}$.

\subsection{Nicalon Cloth and Tow Studies}

Mullite coatings were applied on Nicalon cloth by dip-coating in sols of different wt\% yield of mullite. These studies indicate that better coatings are obtained at 1 to $3 \mathrm{wt} \%$ yield of the oxide coating sol than from the 4.87 wt\% oxide yield sol. The room-temperature XRD pattern of a Nicalon cloth dip-coated in a mullite sol and heat treated at $1050^{\circ} \mathrm{C}$ in air for $30 \mathrm{~min}$ indicates that mullite was deposited. Coated Nicalon tows were used to determine whether Nicalon is damaged during sol-gel processing. Nicalon tows were dip-coated in a mullite sol (MII) at various withdrawal rates, and a slow withdrawal rate $(3.7 \mathrm{~cm} / \mathrm{min})$ resulted in thin $(<100 \mathrm{~nm})$ and much 


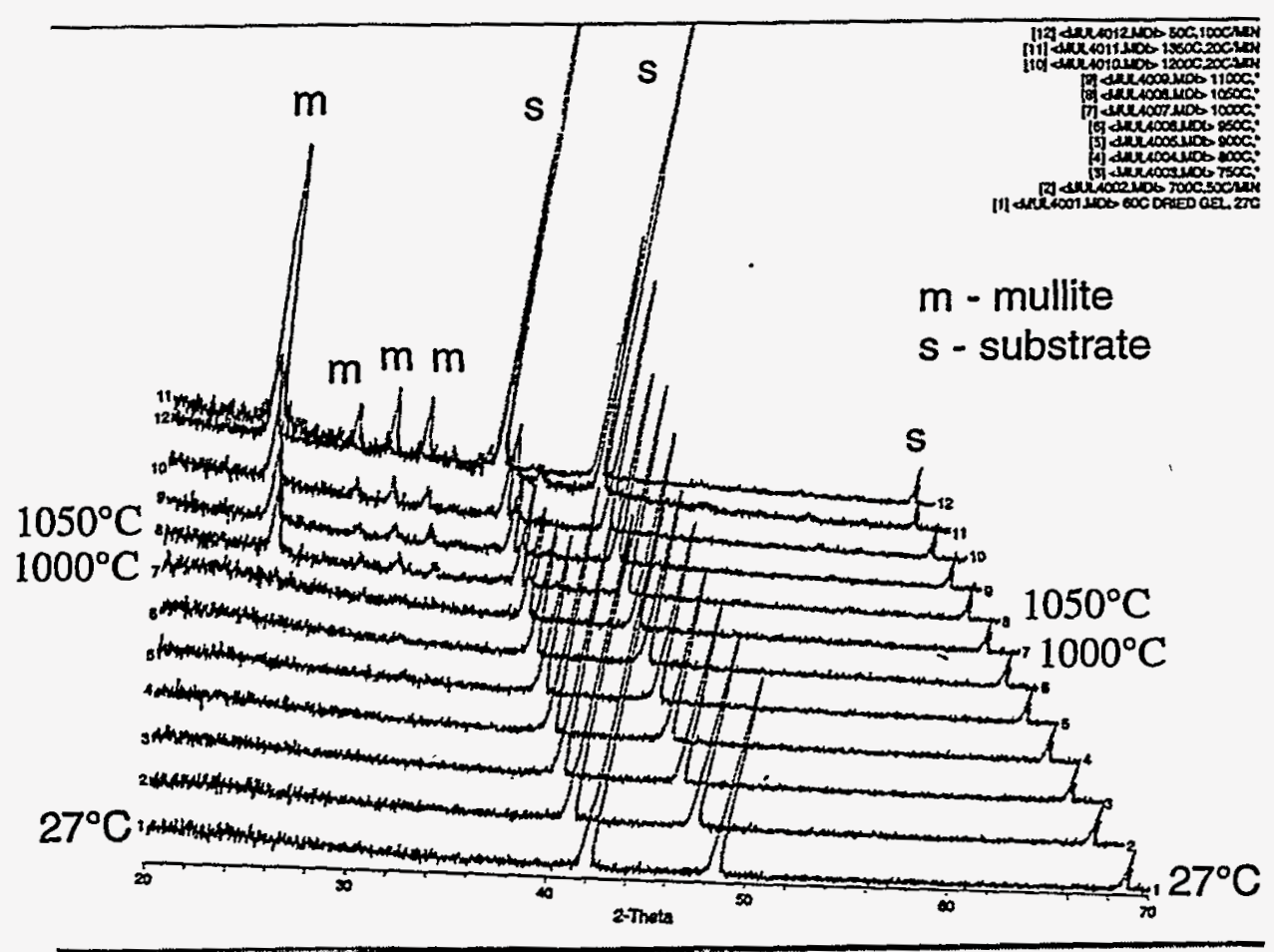

Fig. 8 High-temperature XRD patterns show that mullite crystallization occurs at $1050^{\circ} \mathrm{C}$ from the MII mullite precursor gel. 


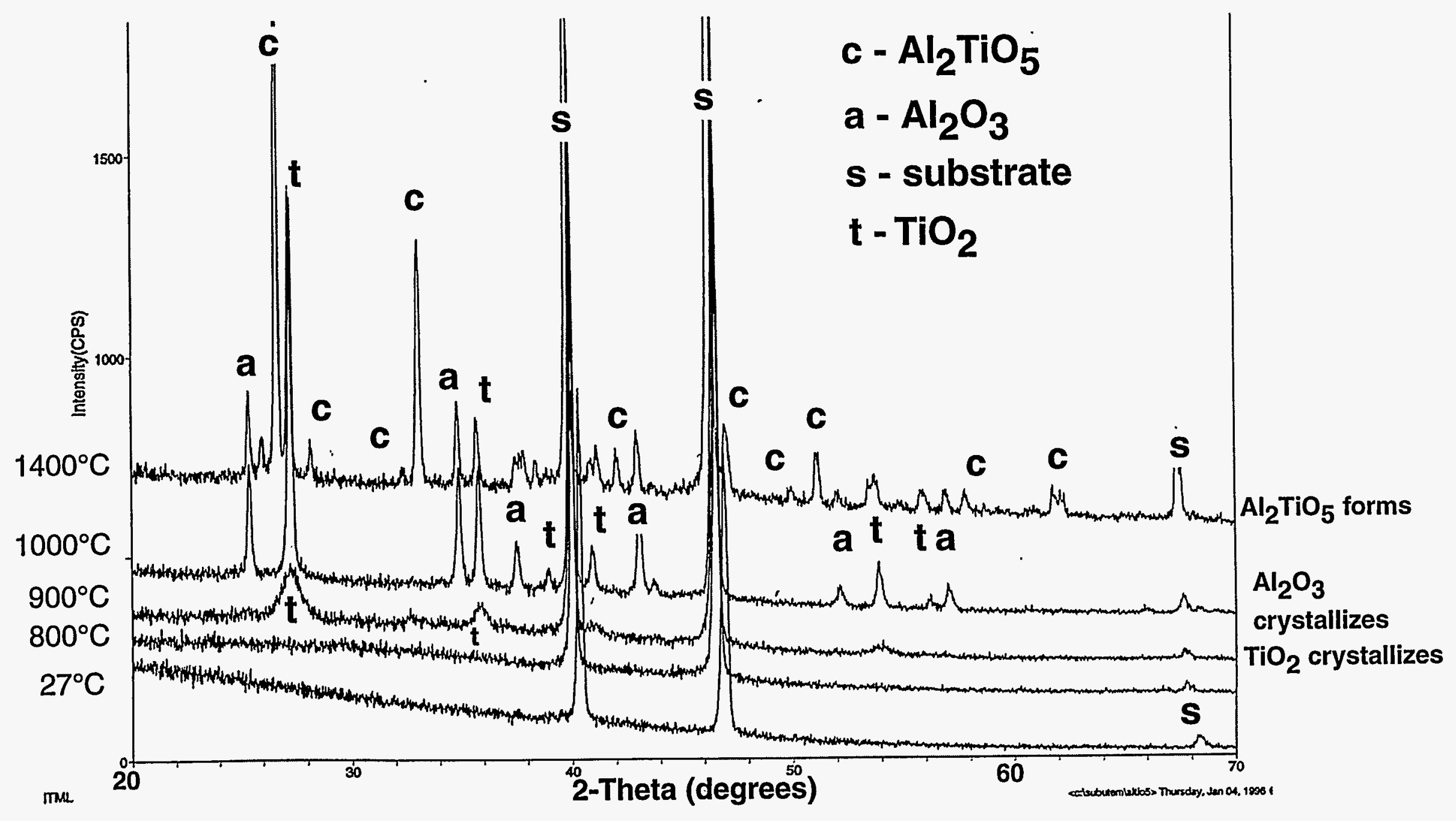

Fig. 9 High-temperature XRD patterns indicate that aluminum titanate forms at $1400^{\circ} \mathrm{C}$. 
more uniform coatings than other withdrawal rates $(>3.7 \mathrm{~cm} / \mathrm{min})$. Figure 10 shows a secondary electron image of a mullite coating on a Nicalon tow heat treated at $1000^{\circ} \mathrm{C}$ along with an energy dispersive X-ray (EDX) spectrum. The EDX analysis (not shown here) indicates that the relative intensity of aluminum to silicon peaks varies from one region to another in the tow.

Nicalon tows coated with a mullite (MI) sol and heat treated at $1000^{\circ} \mathrm{C}$ for $1 \mathrm{~h}$ in air had poor handleability, thus, suggesting that the coated tows were embrittled. In contrast, Nicalon tows coated with a mullite sol obtained from the ASB/TEOS (MII) formulation and similarly heat treated had better handleability. However, longer heating times $(10 \mathrm{~h})$ in air resulted in poor handleability.

The tows dip-coated in an aluminosilicate precursor sol with a lower alumina/silica ratio of 0.75 and heat treated at $1000^{\circ} \mathrm{C}$ in air were less handleable than those dip-coated in a mullite sol (MII). In contrast, the tows dip-coated in an aluminosilicate precursor sol with a high alumina/silica ratio of 3 had good handleability. At the present time, the quantitative measurement of the strength of the fibers before and after coating has not been measured.

Figure 11 shows a secondary electron image and an EDX spectrum of Nicalon tows coated with the aluminum titanate precursor sol and heat treated at $1000^{\circ} \mathrm{C}$ for $1 \mathrm{~h}$ in air. It should be noted that only an alumina and titania mixture would form on Nicalon under this condition. The coated Nicalon tows had good handleability, and this persisted even after longer heating times $(10 \mathrm{~h})$ in air. Since the alumina-titania mixture did not damage the fiber tows at $1000^{\circ} \mathrm{C}$, it was decided that alumina-titania coating would be pursued as an interface coating instead of aluminum titanate. It should be noted that the calculated modulus of the alumina-titania mixture is $331 \mathrm{GPa}$. Although alumina-titania is a high modulus material, it was selected because of the ability to process this coating without damaging the handleability of the fiber after sol-gel processing. 


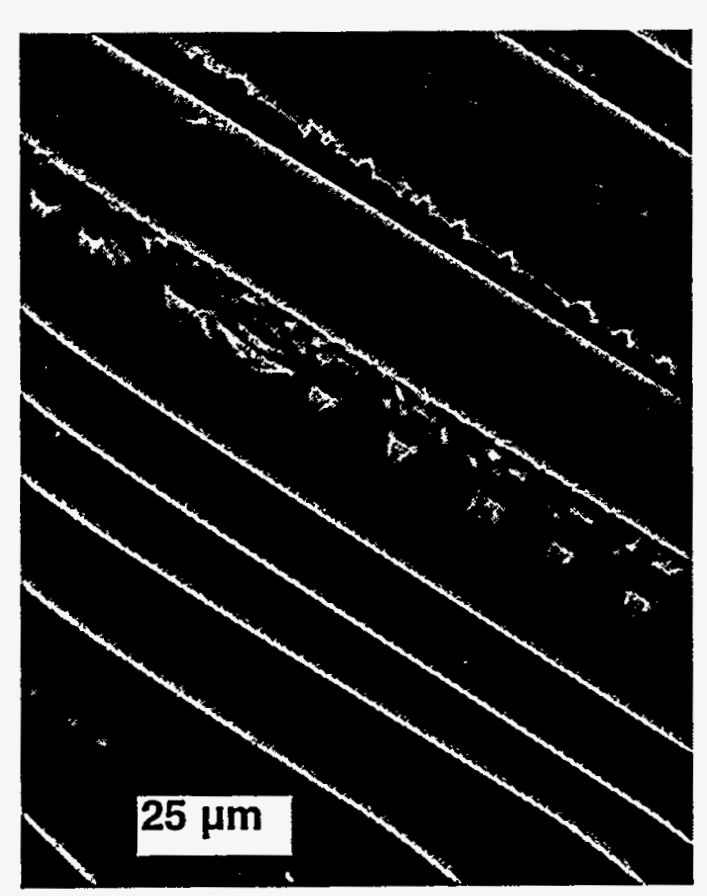

(a)

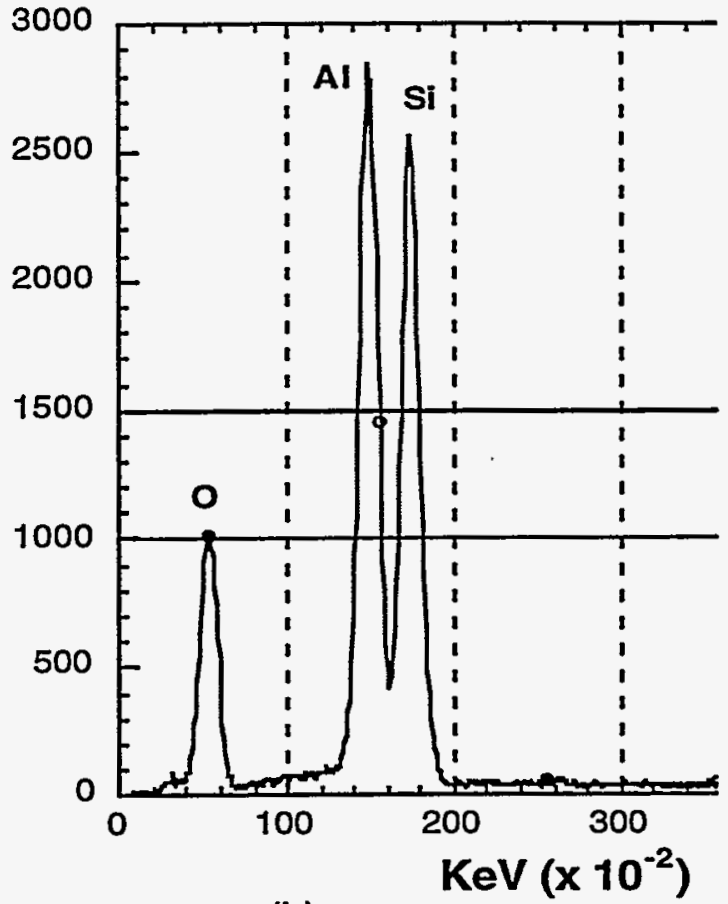

(b)

Fig. 10 Mullite coating on a Nicalon tow heat treated at $1000^{\circ} \mathrm{C}$ (a) a secondary electron image (b) an EDX spectrum 


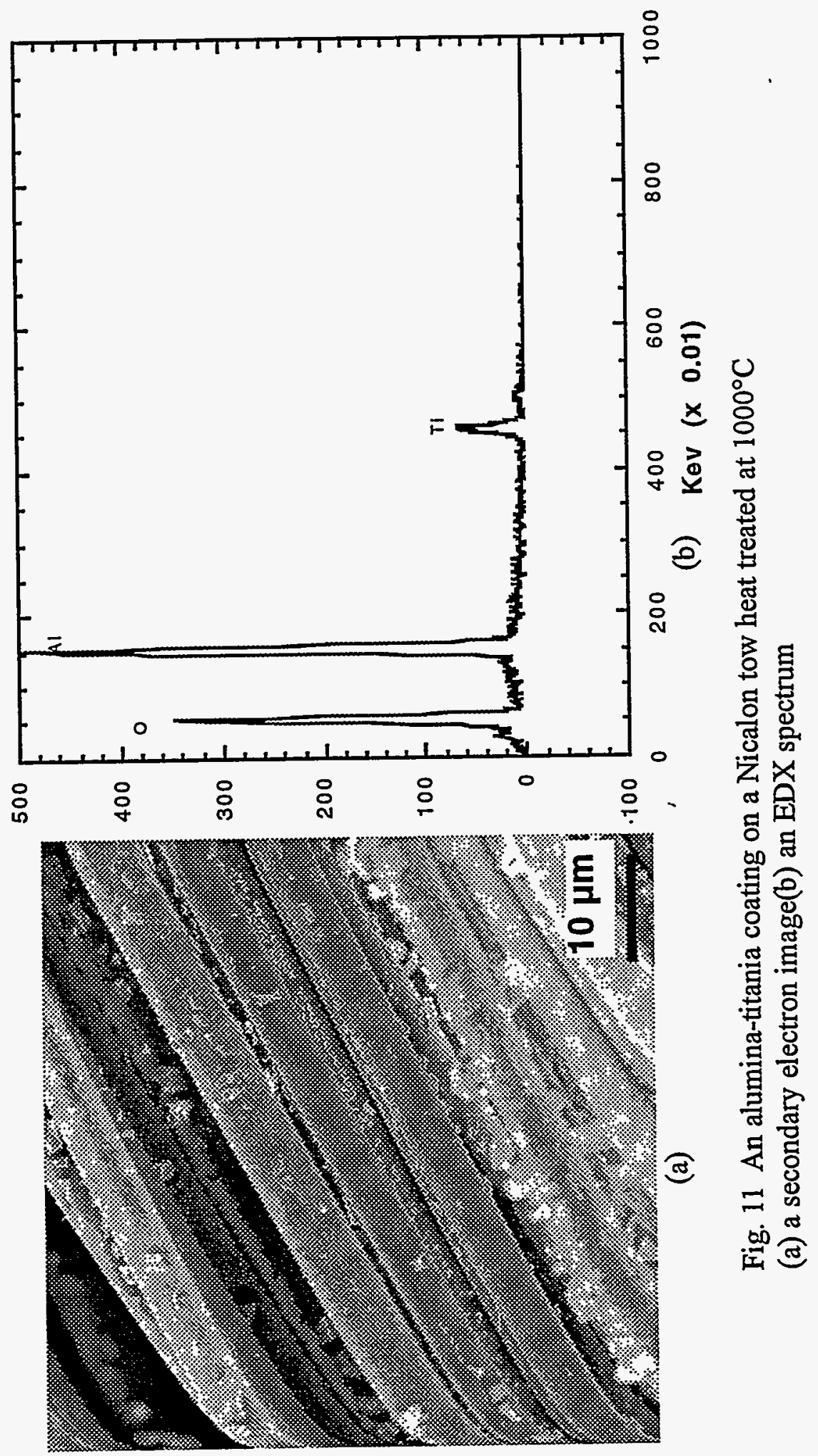




\subsection{Flexure Testing}

Table 3 summarizes the fabricated Nicalon/SiC composites with four different interfaces along with their densities and interface coating thicknesses calculated from weight gain measurements. The flexure strength results of Nicalon/SiC composites with four different interfaces are summarized in Table 4. The damage-tolerant behavior represented in Table 4 and the discussion below corresponds to the composite exhibiting multiple matrix cracking, interface debonding, crack deflection, fiber fracture and fiber slip and pullout. For the first two composites in Table 4, there was no inner C layer between the fiber and the oxide, while the last two composites had an inner C layer (Fig. 3). From Table 4, it is evident that composites without an inner $\mathrm{C}$ layer had low flexure strength $(\leq 122 \mathrm{MPa})$. The composite with a mullite/C interface had low flexure strengths ( $\leq 80 \mathrm{MPa}$ ) both in the as-processed and oxidized condition, and underwent brittle failure (no damage-tolerance). This could be attributed to the fiber degradation during the sol-gel processing of the oxide on the fiber since the Nicalon tows with mullite coating had poor handleability within $10 \mathrm{~h}$ oxidation at $1000^{\circ} \mathrm{C}$ (as mentioned earlier). In contrast, the composite with an $\mathrm{Al}_{2} \mathrm{O}_{3}-\mathrm{TiO}_{2} / \mathrm{C}$ interface displayed damage-tolerant (non-catastrophic failure) behavior in both as-processed and oxidized conditions, but with low flexure strengths ( $\leq 122 \mathrm{MPa}$ ). The damage-tolerant behavior is consistent with the earlier observation that the Nicalon tows with an alumina-titania coating had good handleability even after $10 \mathrm{~h}$ oxidation at $1000^{\circ} \mathrm{C}$ in air. The two composites discussed above highlights that a good handleability of the fiber with the coating may also be an important criterion in influencing its composite behavior.

The composite with a $\mathrm{C} /$ mullite/ $\mathrm{C}$ interface had a moderate flexure strength of $268 \mathrm{MPa}$ in the as-processed condition and retained almost the same strength even after $24 \mathrm{~h}$ oxidation. However, the strength dropped to $200 \mathrm{MPa}$ after $200 \mathrm{~h}$ oxidation and did not undergo significant reduction even after $500 \mathrm{~h}$ oxidation. This composite had damage-tolerant behavior in the as-processed condition and maintained this characteristic even after $500 \mathrm{~h}$ oxidation. 
Table 3. Density and interface coating thicknesses of the fabricated Nicalon/SiC composites

\begin{tabular}{|c|c|c|c|c|c|c|}
\hline \multirow{2}{*}{ CVI\# } & \multirow{2}{*}{ Interface } & \multirow{2}{*}{$\begin{array}{c}\text { Theoretical } \\
\text { Density }\end{array}$} & \multirow{2}{*}{$\begin{array}{l}\text { Density } \\
\left(\mathrm{g} / \mathrm{cm}^{3}\right)\end{array}$} & \multicolumn{3}{|c|}{ Interface Coating Thickness (nm)* } \\
\hline & & & & Inner Carbon & Oxide & Outer Carbon \\
\hline 982 & Mullite/C & 2.92 & $2.33 \pm 0.06$ & - & 272 & 11 \\
\hline 985 & $\mathrm{Al}_{2} \mathrm{O}_{3}-\mathrm{TiO}_{2} / \mathrm{C}$ & 2.94 & $2.41 \pm 0.05$ & - & 174 & 33 \\
\hline 986 & C/Mullite/C & 2.92 & $2.47 \pm 0.06$ & 22 & 204 & 21 \\
\hline 1002 & $\mathrm{Cl} \mathrm{Al}_{2} \mathrm{O}_{3}-\mathrm{TiO}_{2} / \mathrm{C}$ & 2.94 & $2.46 \pm 0.06$ & 28 & 163 & 27 \\
\hline
\end{tabular}

* Calculated from weight gain 
Table 4. Flexure strength results of Nicalon/SiC composites with four different interfaces

\begin{tabular}{|c|c|c|c|c|c|c|c|}
\hline CVI\# & Interface & $\begin{array}{l}\text { Density } \\
\left(\mathrm{g} / \mathrm{cm}^{3}\right)\end{array}$ & As-Processed & $\begin{array}{l}\text { exure Stren } \\
24 \mathrm{~h}\end{array}$ & $\begin{array}{l}\mathrm{MPa}) \\
\text { at } 1000^{\circ} \mathrm{C} \text { i } \\
200 \mathrm{~h}\end{array}$ & $500 \mathrm{~h}$ & $\begin{array}{c}\text { Fracture } \\
\text { Type }\end{array}$ \\
\hline 982 & Mullite/C & $2.33 \pm 0.06$ & $64 \pm 8 *$ & $80 \pm 9 *$ & - & - & Brittle \\
\hline 985 & $\mathrm{Al}_{2} \mathrm{O}_{3}-\mathrm{TiO}_{2} / \mathrm{C}$ & $2.41 \pm 0.05$ & $122 \pm 29 *$ & $112 \pm 24^{*}$ & - & - & Damage-tolerant \\
\hline 986 & C/Mullite/C & $2.47 \pm 0.06$ & $268 \pm 52 *$ & $260 \pm 61 * *$ & $200 \pm 47 * * *$ & $184 \pm 28 * * *$ & Damage-tolerant \\
\hline 1002 & $\mathrm{C} / \mathrm{Al}_{2} \mathrm{O}_{3}-\mathrm{TiO}_{2} / \mathrm{C}$ & $2.46 \pm 0.06$ & $255 \pm 35^{*}$ & $189 \pm 45^{* *}$ & $217 \pm 35 * * *$ & $159 \pm 20 * * *$ & Damage-tolerant \\
\hline
\end{tabular}

$* 12$ flexure bars ${ }^{* *} 6$ flexure bars $* * * 3$ flexure bars

జ 


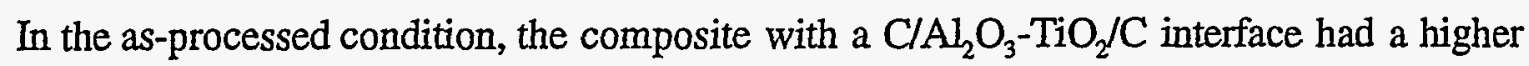
flexure strength $(255 \mathrm{MPa})$ than the composite with an $\mathrm{Al}_{2} \mathrm{O}_{3}-\mathrm{TiO}_{2} / \mathrm{C}$ interface $(122 \mathrm{MPa})$. The composite with a $\mathrm{C} / \mathrm{Al}_{2} \mathrm{O}_{3}-\mathrm{TiO}_{2} / \mathrm{C}$ interface continued to exhibit damage-tolerant behavior even after $500 \mathrm{~h}$ oxidation but with a flexure strength of $159 \mathrm{MPa}$. Figures 12 (a), and (b) show the load versus displacement curve for samples in the as-processed and after $500 \mathrm{~h}$ oxidation for composites with a C/mullite/ $\mathrm{C}$ interface and a $\mathrm{C} / \mathrm{Al}_{2} \mathrm{O}_{3}-\mathrm{TiO}_{2} / \mathrm{C}$ interface, respectively. It is evident from the figure that even after $500 \mathrm{~h}$ oxidation, these samples displayed a non-catastrophic mode of failure.

\subsection{Scanning Electron Microscopy (SEM)}

The fracture surface examination of the Nicalon/SiC composite with a mullite/C interface and alumina-titania/C interface showed very little fiber pullout, which corresponds well with the low flexure strengths of these composites (Table 4). Figure 13 shows a fracture surface of the Nicalon/SiC composite with an alumina-titania/C interface exhibiting limited fiber pullout. In contrast, the Nicalon/SiC composites with a C/alumina/titania/C interface and $\mathrm{C} /$ mullite/C interface exhibited considerable amounts of fiber pullout (Figs. 14 and 15). Figures 14 (a) and (b) show a Nicalon/SiC composite with a C/alumina-titania/C interface in the as-processed condition and after oxidation for $500 \mathrm{~h}$ at $1000^{\circ} \mathrm{C}$ in air. The moderate flexure strength (255 MPa) exhibited by this composite in the as-processed condition is consistent with the observation of a considerable amount of fiber pullout in Fig. 14 (a). After oxidation, this composite exhibited reduced fiber pullout (Fig. 14 (b)). Figure 15 shows a Nicalon/SiC composite with a C/mullite/C interface displaying a substantial amount of fiber pullout even after $500 \mathrm{~h}$ oxidation at $1000^{\circ} \mathrm{C}$ in air.

The manufacturer's Nicalon fiber data sheet indicates that the fiber tensile strength decreases from $1.90 \mathrm{GPa}$ at room temperature to $1.32 \mathrm{GPa}(\sim 31 \%$ reduction $)$ after oxidation for $500 \mathrm{~h}$ at $1000^{\circ} \mathrm{C}$ in air. Preliminary fiber fracture surface examination shows that pits are formed on the fiber surface after $500 \mathrm{~h}$ oxidation of the Nicalon/SiC composite with a C/alumina-titania/C 

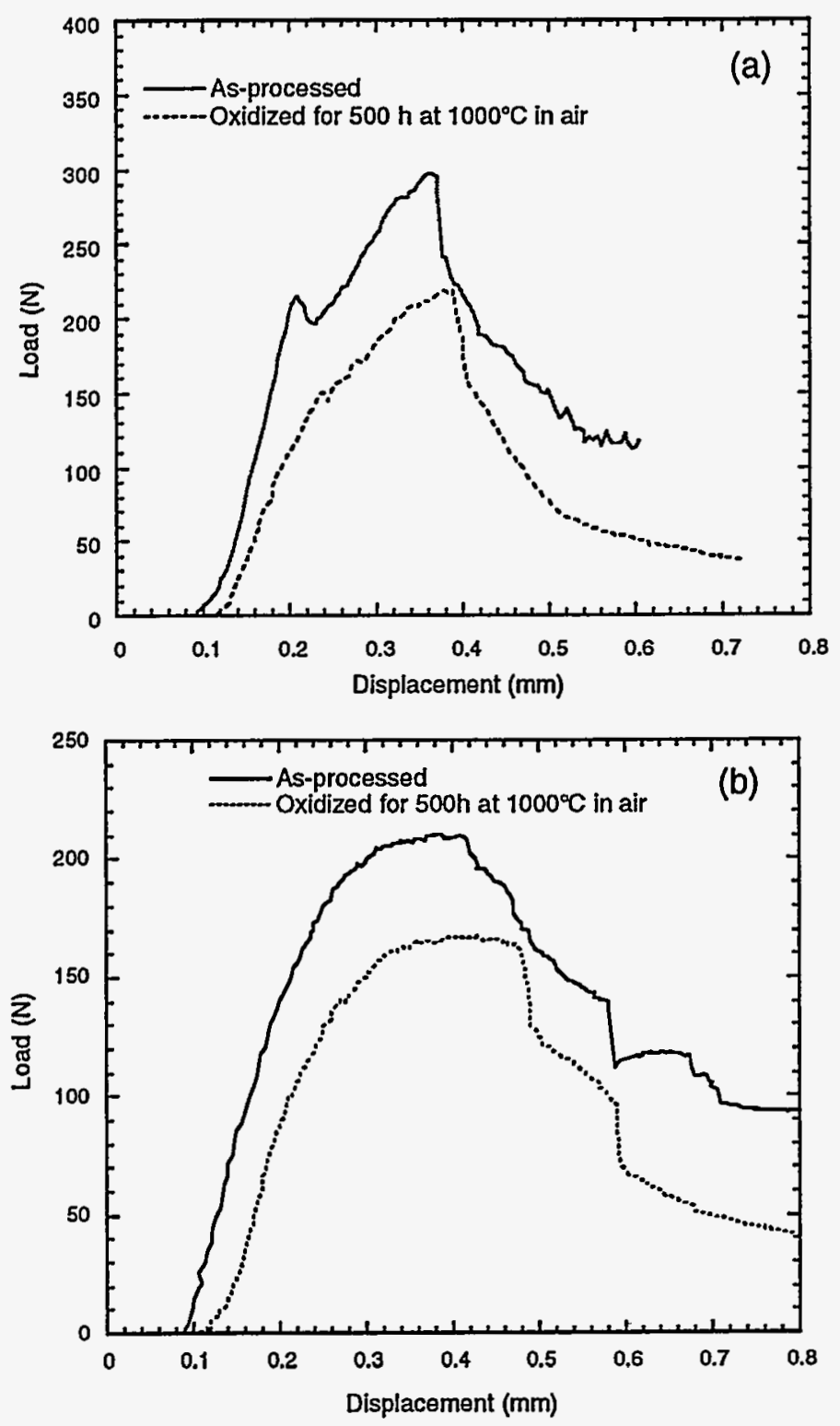

Fig.12 Flexure curves for Nicalon/SiC composites with (a) $\mathrm{C} /$ mullite/C interface and (b) $\mathrm{C} /$ alumina-titania/C interface. Both composites show damage-tolerant behavior even after $500 \mathrm{~h}$ oxidation at $1000^{\circ} \mathrm{C}$ in air. 
62

'วnoIInd Jəqu

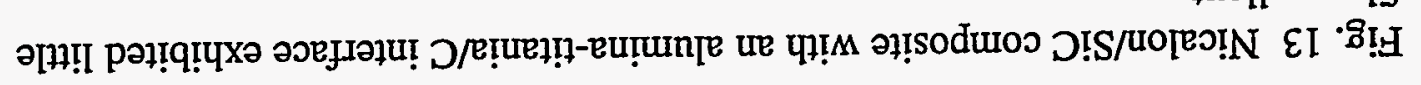

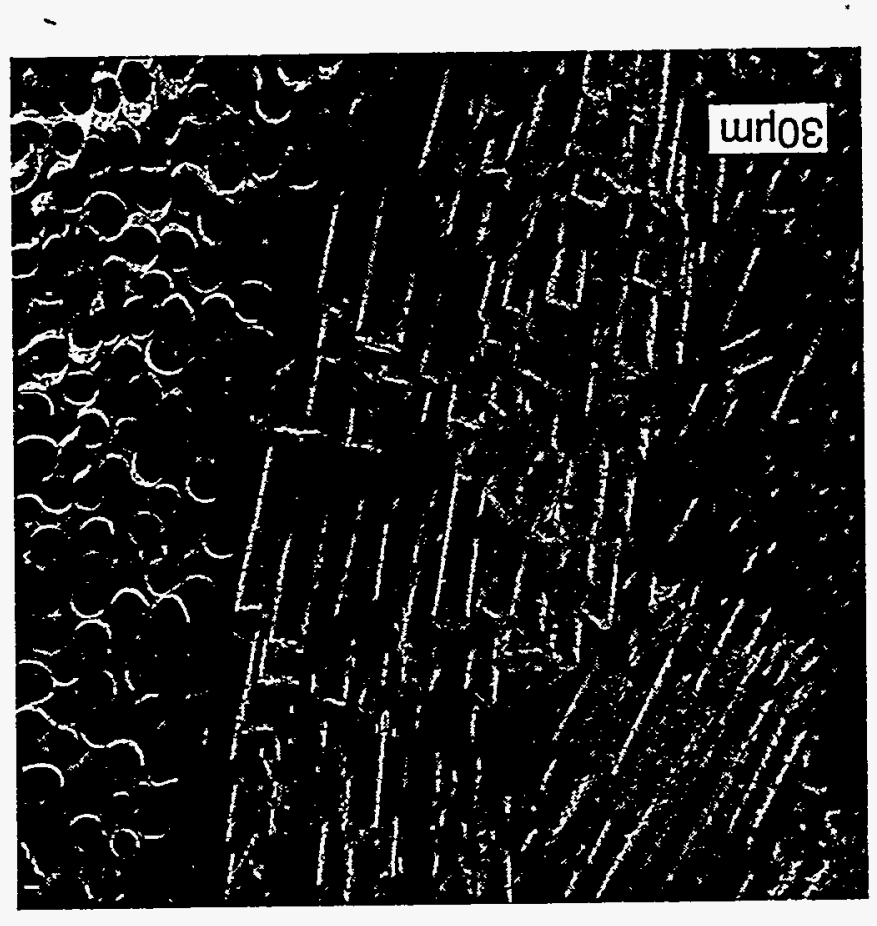



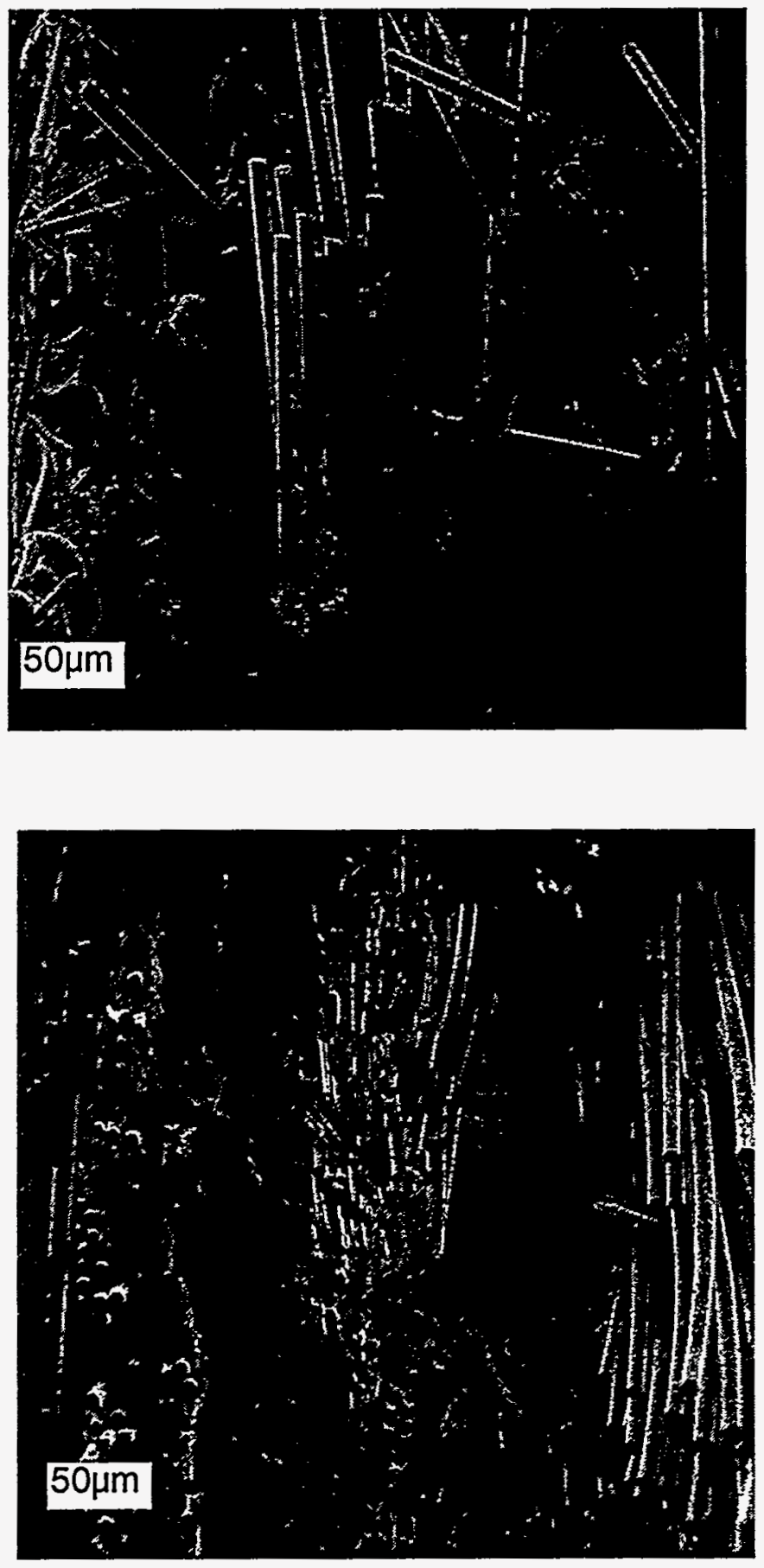

Fig. $14 \mathrm{Nicalon} / \mathrm{SiC}$ composite with a C/alumina-titania/C interface (a) As-processed condition - Substantial amount of fiber pullout (b) Oxidized for $500 \mathrm{~h}$ at $1000^{\circ} \mathrm{C}$ in air - Reduced fiber pullout 


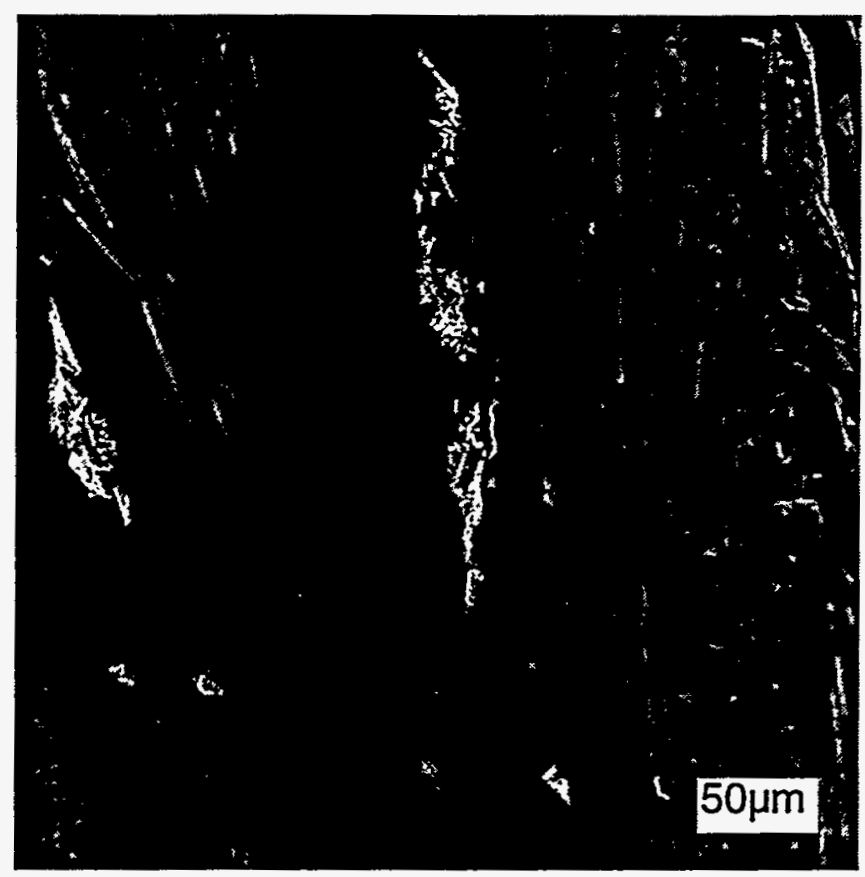

Fig. $15 \mathrm{Nicalon} / \mathrm{SiC}$ composite with a $\mathrm{C} /$ mullite/C interface exhibited substantial amount of fiber pullout even after $500 \mathrm{~h}$ oxidation. 
interface at $1000^{\circ} \mathrm{C}$ (Fig. 16). Consequently, the observed loss in flexure strength after oxidation (about $38 \%$ reduction) of the composite may be due to fiber degradation, and not by virtue of interface degradation. Detailed SEM and transmission electron microscopy studies are currently being conducted to determine the extent of fiber damage and interface coating thickness, respectively. Auger electron microscopy studies are also being conducted to determine where the debonding occurred.

\section{CONCLUSIONS}

Mullite and aluminum titanate precursor sols were developed for Nicalon fiber coating applications. High-temperature X-ray diffraction studies identified that mullite crystallization and aluminum titanate formation occurred around $1050^{\circ} \mathrm{C}$ and $1400^{\circ} \mathrm{C}$, respectively. Since aluminum titanate forms at $1400^{\circ} \mathrm{C}$, it is not possible to deposit it on Nicalon fibers without damaging them. Nicalon tows with an alumina-titania coating mixture had good handleability even after exposure to $1000^{\circ} \mathrm{C}$ for $10 \mathrm{~h}$ in air. Consequently, an alumina-titania interface coating was pursued instead of aluminum titanate. However, Nicalon tows with a mullite coating had poor handleability after exposure to $1000^{\circ} \mathrm{C}$ for $10 \mathrm{~h}$. As a result, the need to protect the fiber by means of a C coating prior to the oxide deposition was recognized.

Nicalon/SiC composites with $\mathrm{C} /$ oxide/C (the oxide interface concept) interfaces exhibited higher flexure strengths and retained damage-tolerant behavior even after $500 \mathrm{~h}$ at $1000^{\circ} \mathrm{C}$ than those of composites with oxide/C interfaces. Among the composites investigated, the composite with a $\mathrm{C} / \mathrm{mullite} / \mathrm{C}$ interface had the highest flexure strength in the as-processed condition and after $500 \mathrm{~h}$ oxidation at $1000^{\circ} \mathrm{C}$. The good handleability of the fiber with the coating after processing may be an important indicator of the subsequent composite behavior. Efforts to replace $\mathrm{C}$ or $\mathrm{BN}$ interfaces with oxidation-resistant interface materials, such as $\mathrm{C} / \mathrm{mullite} / \mathrm{C}$ and $\mathrm{C} / a$ lumina-titania/C interfaces, have met initial success. Continued development and stressed-oxidation tests of these 


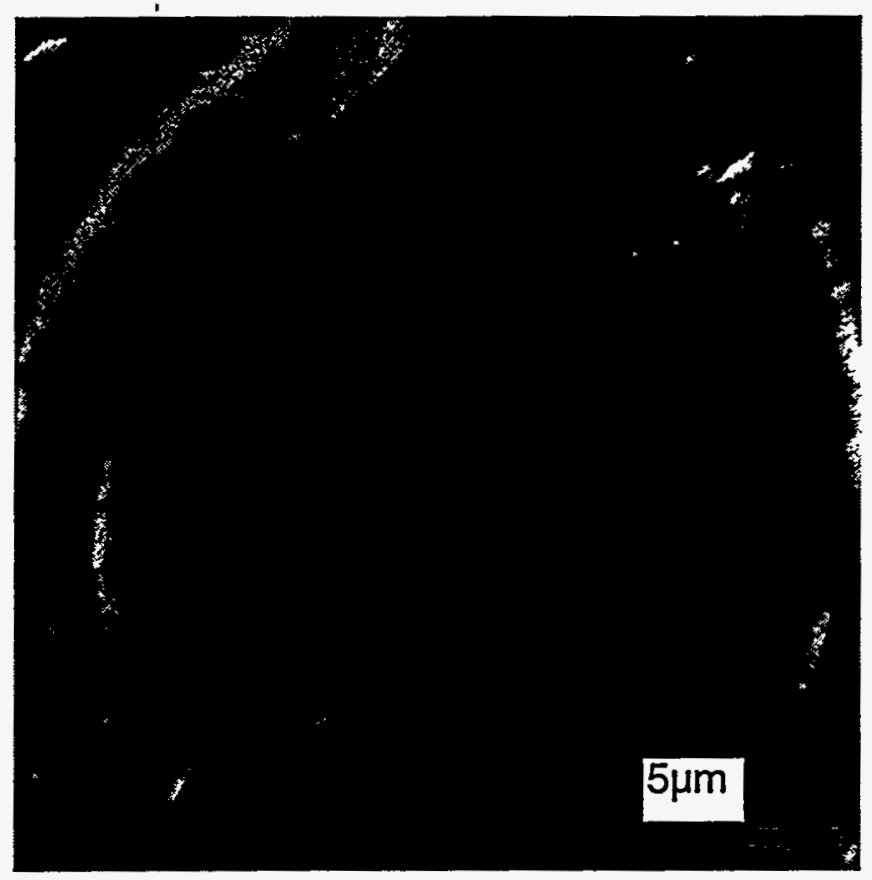

Fig. 16 Pits are formed on the Nicalon fiber surface after $500 \mathrm{~h}$ oxidation in air at $1000^{\circ} \mathrm{C}$ in a Nicalon/SiC composite with a C/alumina-titania/C interface. 
composites with an oxide interface concept need to be conducted to establish their potential as a viable oxidation-resistant interface material.

\section{ACKNOWLEDGMENTS}

The authors are very grateful to Mr. D. P. Stinton, Dr. T. M. Besmann, Mr. W. D. Porter, Dr. S. T. Misture of the Oak Ridge National Laboratory for their significant involvement, constructive suggestions, and the use of their facilities during the course of this work. Mr. J. W. Hurley deposited the C-coating and the SiC matrix at the Oak Ridge National Laboratory. Research sponsored by the U.S. Department of Energy, Fossil Energy Advanced Research and Technology Development Materials Program, DOE/FE AA 1510100, Work Breakdown Structure Element UT-1(B) under subcontract 11B-99732C-S64 to the University of Tennessee, and High Temperature Materials Laboratory User Program under contract DE-AC05-96OR22464 with Lockheed Martin Energy Research Corporation.

\section{REFERENCES}

1. I. W. Donald and P. W. McMillan, J. Mater. Sci. 11, 949 (1976).

2. M. Karnitz, D. F. Craig, and S. L. Richlen, Am. Ceram. Soc. Bull. 70, 430 (1991).

3. P. F. Becher and G. C. Wei, Mater. Sci. Eng. A107, 257 (1989).

4. H. Kodama, T. Suzuki, H. Sakamoto, and T. Miyoshi, J. Am. Ceram. Soc. 73, 678 (1990).

5. D. B. Marshall and A. G. Evans, J. Am. Ceram. Soc. 68 [5], 225 (1985).

6. T. M. Besmann, B. W. Sheldon, R. A. Lowden, and D. P. Stinton, Science 253, 1104 (1991).

7. J. K. Weddel, J. Text. Inst., 81 [4], 333 (1990).

8. Information from fiber data sheet and personal communication from Technical Personnel of: 3M, Textron, BP, Nippon Carbon, Ube Industries, ICI, Tonen, Dow Corning, MER, Saphikon, Mitsui Mining, and Sumitomo Chemical. 
9. T. L. Tompkins, "Ceramic Oxide Fibers: Building Blocks for New Applications," Ceramic Industry, April, 1995.

10. H. G. Sowman and D. D. Johnson, "Oxide Fibers from Chemical Ceramic Process," pp. 122-140 in Fiber Reinforced Ceramic Composites: Materials, Processing and Technology, Edited by K. S. Mazdiyasni, Noyes Publications, New Jersey, 1990.

11. J. Persh, Ceram. Eng. Sci. Proc., 9 [7-8], 529 (1988).

12. K. K. Chawla, Ceramic Matrix Composites, Chapman and Hall, London, 1993.

13. R. J. Kerans, Scripta Metall. and Mater., 32, 505 (1995).

14. R. A. Lowden, Ceram. Trans. 19, 619 (1991).

15. S. Shanmugham, D. P. Stinton, F. Rebillat, A. Bleier, T. M. Besmann, E. Lara-Curzio, and P. K. Liaw, Ceram. Eng. Sci. Proc. 16, 389 (1995).

16. R. Naslain, Ceram. Trans. 58, 23 (1995).

17. P. F. Tortorelli, S. Nijhawan, L. Riester, and R. A. Lowden, Ceram. Eng. Sci. Proc. 14, 358 (1993).

18. R. A. Lowden, O. J. Schwarz, and K. L. More, Ceram. Eng. Sci. Proc. 14, 375 (1993).

19. R. A. Lowden, "Fiber Coatings and the Mechanical Properties of a Continuous FiberReinforced SiC Matrix Composite," pp. 157-71 in Designing Ceramic Interfaces II-Understanding and Tailoring Interfaces for Coating, Composite, and Joining Applications, Proceedings of the Second European Colloquium, Edited by S. D. Peteves, Commision of the European Communities, Netherlands, 1993.

20. R. A. Lowden and D. P. Stinton, Ceram. Eng. Sci. Proc. 9, 705 (1988).

21. R. A. Lowden, ORNL/TM-11039, Oak Ridge National Laboratory, Oak Ridge, TN, March 1989.

22. D. M. Walukas, "A Study of the Mechanical Properties and Oxidation Resistance of Nicalon/SiC Composites with Sol-Gel Derived Oxide Interfacial Coatings," Masters Thesis, The University of Tennessee, Knoxville, Tennessee, May 1993.

23. C. H. Hsueh, P. F. Becher, and P. Angelini, J. Am. Ceram. Soc. 71, 929 (1988).

24. S. Shanmugham, P. K. Liaw, D. P. Stinton, T. M. Besmann, K. L. More, A. Bleier, W. D. Porter, and S. T. Misture, in press (Ceram. Eng. Sci. Proc. 17, 1996).

25. B. E. Yoldas, J. Mater. Sci. 27, 6667 (1992).

26. D. P. Stinton, T. M. Besmann, and R. A. Lowden, Am. Ceram. Bull. 67, 350 (1988). 
3M COMPANY

Ceramic Materials Department

201-4N-01 3M Center,

St. Paul, MN 55144

M. A. Leitheiser

AIR PRODUCTS AND CHEMICALS

P.O. Box 538

Allentown, PA 18105

S. W. Dean

ALLISON GAS TURBINE DIVISION

P.O. Box 420

Indianapolis, IN 46206-0420

P. Khandelwal (Speed Code W-5)

R. A. Wenglarz (Speed Code W-16)

AMA RESEARCH \& DEVELOPMENT CENTER 5950 Mclntyre Street

Golden, CO 80403

T. B. Cox

ARGONNE NATIONAL LABORATORY

9700 S. Cass Avenue

Argonne, IL 60439

W. A. Ellingson

J. P. Singh

ARGONNE NATIONAL LABORATORY-WEST

P.O. Box 2528

Idaho Falls, ID 83403-2528

S. P. Henslee

BABCOCK \& WILCOX

Domestic Fossil Operations

20 South Van Buren Avenue

Barberton, $\mathrm{OH} 44023$

M. Gold

BRITISH COAL CORPORATION

Coal Technology Development Division

Stoke Orchard, Cheltenham

Glocestershire, England GL52 4ZG

J. Oakey
CANADA CENTER FOR MINERAL \& ENERGY

TECHNOLOGY

568 Booth Street

Ottawa, Ontario

Canada K1A OG1

R. Winston Revic

Mahi Sahoo

DOE

DOE OAK RIDGE OPERATIONS

P.O.Box 2001

Oak Ridge, TN 37831

Assistant Manager for

Energy Research and Development

DOE

DOE OAK RIDGE OPERATIONS

P. O. Box 2008

Building 4500N, MS 6269

Oak Ridge, TN 37831

-M. H. Rawlins

DOE

OFFICE OF BASIC ENERGY SCIENCES

Materials Sciences Division

ER-131

19901 Germantown Road

Germantown, MD 20874-1290

H. M. Kerch

DOE

IDAHO ÖPERATIONS OFFICE

P. O. Box 1625

Idaho Falls, ID 83415

J. B. Malmo

DOE

MORGANTOWN ENERGY TECHNOLOGY

CENTER

P.O. Box 880

Morgantown, WW 26505

R. C. Bedick

D. C. Cicero

F. W. Crouse, Jr.

$R$. A. Dennis

N. T. Holcombe

W. J. Huber

T. J. McMahon

J. E. Notestein 
DOE

OFFICE OF FOSSIL ENERGY

FE-72

19901 Germantown Road

Germantown, MD 20874-1290

J. P. Carr

\section{DOE}

OFFICE OF VEHICLE AND ENERGY R\&D

CE-151 Forrestal Building

Washington, DC 20585

R. B. Schulz

DOE

PITTSBURGH ENERGY TECHNOLOGY

CENTER

P.O. Box 10940

Pittsburgh, PA 15236

A. L. Baldwin

G. V. McGurl

L. A. Ruth

T. M. Torkos

DOW CORNING CORPORATION

3901 S. Saginaw Road

Midland, Ml 48686-0995

H. Atwell

EC TECHNOLOGIES

3614 Highpoint Drive

San Antonio, TX 78217

D. J. Kenton

ELECTRIC POWER RESEARCH INSTITUTE

P.O. Box 10412

3412 Hillview Avenue

Palo Alto, CA 94303

W. T. Bakker

J. Stringer

EUROPEAN COMMUNITIES JOINT

RESEARCH CENTRE

Petten Establishment

P.O. Box 2

1755 ZG Petten

The Netherlands

M. Van de Voorde

GA TECHNOLOGIES. INC.

P.O. Box 85608

San Diego, CA 92138

T. D. Gulden
GEORGIA INSTITUTE OF TECHNOLOGY

Materials Science \& Engineering (0245)

Bunger-Henry Building, Room 276

Atlanta, GA 30332-0245

T. L. Starr

IDAHO NATIONAL ENGINEERING

LABORATORY

P. O. Box 1625

Idaho Falls, ID 83415

B. H. Rabin

LAVA CRUCIBLE-REFRACTORIES CO.

P.O. BoX 278

Zelienople, PA 16063

T. Mulholland

LAWRENCE LIVERMORE NATIONAL

LABORATORY

P.O. Box 808, L-325

Livermore, CA 94550

W. A. Steele

LOS ALAMOS NATIONAL LABORATORY

P.O. Box 1663

Los Alamos, NM 87545

J. D. Katz

NATIONAL MATERIALS ADVISORY BOARD National Research Council

2101 Constitution Avenue

Washington, DC 20418

K. M. Zwilsky

OAK RIDGE NATIONAL LABORATORY

P.O. Box 2008

Oak Ridge, TN 37831

P. T. Carlson

N. C. Cole

F. D. Johnson (5 copies)

R. R. Judkins

E. L. Long, Jr.

D. P. Stinton

M. R. Upton

OFFICE OF NAVAL RESEARCH

Code 431,800 N. Quincy Street

Arlington, VA 22217

S. G. Fishman

Page 2 of 3 
SANDIA NATIONAL LABORATORIES

Department 6211, MS 0710

Albuquerque, NM 87185

R. J. Buss

G. A. Carlson

A. G. Sault

SHELL DEVELOPMENT COMPANY

P.O. Box 1380

Houston, TX 77251-1380

L.W. R. Dicks

TENNESSEE VALLEY AUTHORITY

Energy Demonstration \& Technology MR2N58A

Chattanooga, TN 37402-2801

C. M. Huang

THE JOHNS HOPKINS UNIVERSITY

Materials Science \& Engineering

Maryland Hall

Baltimore, MD 21218

R. E. Green, Jr.

THE MATERIALS PROPERTIES COUNCIL, INC.

United Engineering Center

345 E. Forty-Seventh Street

New York, NY 10017

M. Prager

THE NORTON COMPANY

High Performance Ceramics Division Goddard Road

Northborough, MA 01532-1545

N. Corbin

THE TORRINGTON COMPANY

Advanced Technology Center

59 Field St.

Torrington, CT 06790

W. J. Chmura

UNION CARBIDE CORPORATION

Linde Division

P.O. Box 44

175 East Park Drive

Tonawanda, NY 14151-0044

Harry Cheung
UNITED TECHNOLOGIES RESEARCH

CENTER

MS 24, Silver Lane

East Hartford, CT 06108

K. M. Prewo

UNIVERSITY OF TENNESSEE

Dept of Materials Science and Engineering

Knoxville, TN 37996-2200

Peter Liaw

UNIVERSITY OF WASHINGTON

Department of Materials Science and

Engineering

101 Wilson, FB-10

Seattle, WA 98195

T. G. Stoebe

VIRGINIA POLYTECHNIC INSTITUTE \& STATE UNIVERSITY

Department of Materials Engineering

Blackburg, VA 24601

W. A. Curtin

K. L. Reifsnider

WESTERN RESEARCH INSTITUTE

365 N. 9th Street

P.O. Box 3395

University Station

Laramie, WY 82071

V. K. Sethi

WESTINGHOUSE ELECTRIC CORPORATION Research and Development Center

1310 Beulah Road

Pittsburgh, PA 15235

S. C. Singhal 